\title{
Legacies of British Colonial Violence: Viewing Kenyan Detention Camps through the Hanslope Disclosure
}

1. Samera Esmeir, Juridical Humanity (Stanford: Stanford University Press, 2012); A number of works have recently been published that seek to re-narrate colonial histories, with a particular emphasis on the role of law in at once Q2 creating and marginalizing colonial subjects. ${ }^{1}$ Focusing on mid-twentieth century detention camps in the British colony of Kenya, this article illuminates a colonial history that was deeply buried in a Foreign and Commonwealth Office (FCO) building for many years. As such, the analysis supports the revelatory work of David Anderson and Caroline Elkins, who highlighted the violence that underpinned British detention and interrogation practises in Kenya. ${ }^{2}$ In particular, the article explores recently Fabian Klose, Human Rights in the Shadow of Colonial Violence: The Wars of Independence in Kenya and Algeria (Pennsylvania: University of Pennsylvania Press, 2009); Roland Burke, Decolonization and the Evolution of Human Rights (Philadelphia: University of Pennsylvania Press, 2010); Daniel Maul, Human Rights, Development and

Decolonization: The International Labour Organization, 1940-70 (Palgrave Macmillan, 2012); and Steven Pierce and Anupama Rao, eds. Discipline and the Other Body (Durham and London: Duke University Press, 2006).

2. David Anderson: Histories of the Hanged: The Dirty War in Kenya and the End of Empire (New York: W.W. Norton, 2005); and Caroline Elkins, Imperial Reckoning: The Untold Story of Britain's Gulag in Kenya (New York: H. Holt, 2005).

Dr. Duffy is a is a lecturer in human rights law at the Irish Centre for Human Rights National University of Ireland, Galway< <aduffy@nuigalway.ie.>. This research was partially funded by the Department of Foreign Affairs' Andrew Grene scholarship in conflict resolution. The author thanks Dr. Kathleen Cavanaugh, Professor David Anderson, and Dr. Noelle Higgins for invaluable comments on earlier drafts of this article, and is indebted to the beneficial comments provided by Law and History Review's anonymous reviewers. The author is responsible for any remaining errors. 
declassified colonial files, and pieces together a picture of administrative subterfuge, suppression of facts, and whitewashing atrocities, threaded through with official denial, which long outlived its colonial genesis. Against the hypothesis that detention laws created an architecture of destruction and concomitant custodial violence in Kenya, the article establishes that an accountability deficit is the legacy of detention without trial as it was practiced in colonial Kenya. By untangling a complex web of colonial records and government papers relating to Kenya, this article reveals the often insurmountable pressure that was exerted to conceal evidence of detainee violence, and the role of a highly sophisticated propaganda machine that controlled the public narrative of a violent incident when outright denial was impossible.

In an earlier Law and History Review forum, John Wertheimer argued that the legacy of colonial legal racism persists today, and it is, therefore, important to comprehend the "conceptual and material consequences" of these laws. ${ }^{3}$ It is striking that several British colonies experienced insurgencies prior to independence, ${ }^{4}$ and, as a response, emergency laws and ordinances were enacted that targeted indigenous peoples, and, more specifically, groups that would not demonstrate loyalty to the British Crown. This was all too true in Kenya, where detention of enemy suspects in an expansive network of camps, ${ }^{5}$ underpinned by laws passed by the governor or approved by an unelected executive council, was part of the military strategy designed to tackle the Mau Mau insurgency. ${ }^{6}$ At the center of

3. John Wertheimer, "Introduction," Law and History Review 29 (2011): 469.

4. Which, of course, were not unique to British colonies, Rita Maran, Torture: The Role of Ideology in the French-Algerian War (New York: Praeger Publishers, 1989); and Marnia Lazreg, Torture and the Twilight of Empire: From Algiers to Baghdad (Princeton: Princeton University Press, 2008); see also A. W. Brian Simpson for other British end of empire insurgencies, Human Rights and the End of Empire: Britain and the Genesis of the European Convention (Oxford: Oxford University Press, 2001); and John Newsinger, British Counterinsurgency: From Palestine to Northern Ireland (New York: Palgrave Macmillan, 2002).

5. Kenya, with a complex of more than 100 camps, had a greater number of detainees per target population (Kikuyu) than any other British colony where detention without trial was used, see David French, The British Way in Counter-Insurgency, 1945-1967 (Oxford; New York: Oxford University Press, 2012), 111.

6. For more on British responses to the Mau Mau insurgency, see Daniel Branch, Defeating Mau Mau, Creating Kenya: Counterinsurgency, Civil War, and Decolonization (Cambridge: Cambridge University Press, 2009); Huw Bennett, "The Mau Mau Emergency as Part of the British Army's Post-War Counter-Insurgency Experience," Defense \& Security Analysis 23 (2007): 143-63; John Lonsdale, "Mau Maus of the Mind: Making Mau Mau and Remaking Kenya," The Journal of African History 31 (1990): 393-421; John Newsinger, "Minimum Force, British Counter-Insurgency and the Mau Mau Rebellion," Small Wars \& Insurgencies 3 (1992): 47-57; and Thomas 
the Mau Mau rebellion was a struggle against a system of racial discrimination that maintained white Europeans at the top of the hierarchy in Kenya, with access to and ownership of the best lands, and control over government and administrative structures, while many Kenyan tribes, such as the Kikuyu, labored and toiled in substandard lands and plots of ever decreasing size. ${ }^{7}$ During the Second World War, white settlers in Kenya experienced an economic boom resulting from the market demands for agricultural produce caused by shortages in Europe. ${ }^{8}$ When new crops were introduced to the colony, accompanied by intensive farming methods and increased mechanization, many African "squatters," some of whom had lived there for generations, were forced off European farms into homelessness and destitution in urban areas. Fabian Close elucidates on the multifactorial causes of African protest in Kenya, "the deterioration of African living standards, the disappointment over unfulfilled expectations raised during the war, the worsening of the squatter problem," and, in particular, frustration with increased colonial involvement in all facets of Kenyan life. ${ }^{9}$ The deterioration in living conditions disproportionately affected the Kikuyu, ${ }^{10}$ and in his book, The Kenya Question: An African Answer, Tom Mboya described "the situation in his homeland as socially and politically unjust in light of the pressing problem of land distribution, open racial discrimination, and the total hegemony of Europeans."11 Mboya, one of only eight African members elected to the Legislative Council in 1957, concluded that the development of the Mau Mau movement was a direct "consequence of years of frustration and bitterness among the African population." 12

Mockaitis, "Minimum Force, British Counter-Insurgency and the Mau Mau Rebellion: A Reply," Small Wars \& Insurgencies 3 (1992): 87-89.

7. See, generally, John Overton, "The Origins of the Kikuyu Land Problem: Land Alienation and Land Use in Kiambu, Kenya, 1895-1920," African Studies Review 31 (1988): 109-26; and Frank Furedi, "The Social Composition of the Mau Mau Movement in the White Highlands," The Journal of Peasant Studies 1 (1974): 486-505.

8. For more on the powerful influence of the white settler in British politics, see Frank Kitson, Bunch of Five (London: Faber, 1977), 6-7.

9. One of the most authoritative texts on this process is David Throup's, Economic and Social Origins of Mau Mau 1945-53 (London: Currey, 1987). See also Klose, Human Rights in the Shadow of Colonial Violence, 65-66.

10. Bruce Berman, "Bureaucracy and Incumbent Violence: Colonial Administration and the Origins of the 'Mau Mau' emergency in Kenya," British Journal of Political Science 6 (1976): 143-75.

Q11 11. Tom Mboya, The Kenya Question: An African Answer (Fabian Colonial Bureau, 1956).

12. Mboya referenced in Klose, Human Rights in the Shadow of Colonial Violence, 197. 
Fiona Mackenzie's work examines the agricultural crisis that developed in the Kikuyu reserves as a result of overpopulation. ${ }^{13}$ The Kikuyu were disaffected by evictions, forced labor, unemployment, and landlessness, with consequent urban pressures, and these factors galvanized a rapidly growing movement with an intricate "oathing" process at its core. ${ }^{14}$ Unlike their moderate counterparts, Mau Mau adherents promoted the use of violence to eradicate British colonial rule. ${ }^{15}$ From the outset, the colonial administration and metropolitan government portrayed the conflict in Kenya as a "clash of progress and atavism, of good and evil," rooted in the "collective insanity" of the Kikuyu. ${ }^{16}$ However, Bruce Berman regards Mau Mau violence as a response to the pre-emptive or "incumbent violence" of colonial authorities, thus illuminating the complicity of the Kenyan administration in "shaping the origins and intensity of conflict." 17 To the network of prison and labor camps already in existence prior to the emergency, ${ }^{18}$ Florence Bernault estimates that approximately fifty detention camps were added. ${ }^{19}$ From 1953 to 1960 , between 80,000 and 150,000 Mau Mau suspects were detained without trial in a variety of camps; some pre-existing, others hastily built "temporary" structures, and many characterized by poor living conditions. ${ }^{20}$ An elaborate detention

13. Fiona Mackenzie, Land, Ecology and Resistance in Kenya, 1880-1952 (Edinburgh: Edinburgh University Press, 1998).

14. Elkins, Imperial Reckoning, 22-28. Frank Kitson also describes the significance of oathing among the Kikuyu tribe, and remarks that "[d]espite the fact that some Christian influence had been disseminated in the half-century preceding the outbreak of the Emergency, nearly all the Kikuyu believed in the power of oaths in the same way as mediaeval Englishmen believe in witchcraft," in Bunch of Five, 8.

15. Klose, Human Rights in the Shadow of Colonial Violence, 68.

16. Frederick Cooper, Decolonization and African Society: The Labour Question in French and British Africa, (Cambridge: Cambridge University Press, 1996), 348, 351.

17. Bruce Berman, "Bureaucracy and Incumbent Violence: Colonial Administration and the Origins of the 'Mau Mau' Emergency in Kenya," British Journal of Political Science 6 (1976): 143. Carl Rosberg and John Nottingham also point to the colonial administration's failure to introduce significant reforms as a key contributing factor to the emergence of the Mau Mau movement in The Myth of "Mau Mau": Nationalism in Kenya (New York: Praeger, 1966).

18. Daniel Branch describes the pre-emergency detention network of camps as a "carceral archipelago," see "Imprisonment and Colonialism in Kenya, C. 1930-1952: Escaping the Carceral Archipelago," International Journal of African Historical Studies 38 (2005): 256.

19. Florence Bernault, ed., A History of Prison and Confinement in Africa (Portsmouth: Heinemann, 2003), 13.

20. The figure of 80,000 detainees is propounded in the official record, whereas David Anderson estimates that the maximum number who may have been detained to be 150,000 persons, Histories of the Hanged, 5. Anderson later clarified this figure, by stating that the actual numbers detained was probably between 100,000 and 110,000 (personal correspondence with David Anderson). In Imperial Reckoning, Elkins claims that between 
system was created, infused with theories of Kikuyu psychopathology, underpinned by psychologically rehabilitative measures to "cure" detainees of their infected minds. ${ }^{21}$ The concept of rehabilitation through confession permeated the system, and those who resisted this approach were variously labelled "recalcitrant," "irredeemable," and "irreconcilable." Camps were put under the administration of the "Department of Community Development and Rehabilitation," 22 and the system was conceptualized as a "pipeline," with "hardcore" Kikuyu who were labelled as "Z" or "black" detained in remote high security encampments, eventually to be relabelled as "white," and passed through the pipeline to open camps before release and reintegration into society. To become "white" and successfully exit the detention pipeline the detainee had to demonstrate an attitudinal change: to confess taking the Mau Mau oath, to provide detail on the crimes committed, and to further demonstrate that he or she was once again a "useful citizen" through hard work and labor. ${ }^{23}$ Detainees were excluded from the public sphere and were prevented from contributing to debate or commenting on conditions within the camps. ${ }^{24}$ Nevertheless, occasionally information emerged that testified to a severe regime controlled by European officers and "loyalist" warders, who subjected detainees to violence with impunity. ${ }^{25}$ Materials unearthed from the Hanslope

160,000 and 320,000 Kikuyu were detained during the emergency, but this assertion has been called into question, see Guardian article by John Willis, "External Ombudsman's decision on David Elstein's complaint," April 72008 http://www.guardian.co.uk/theguardian/ 2008/apr/07/opendoor (April 18, 2015).

Q12 21. The National Archives (hereafter TNA) FCO 141/6321: Office of the Commissioner Kenya Prisons to the Secretary for Defence, May 31, 1956. See also, Pierce and Rao, Discipline and the Other Body, 1.

22. Cooper, Decolonization and African Society, 351.

23. Ibid., and see TNA FCO 141/5666: Athi River Rehabilitation Camp, Moral Rearmament Army, document circa August 1953.

24. Although detainees were allowed to send and receive one letter per month, the officer in charge of the detention camp could confiscate "any book or paper which, in his opinion, contains any objectionable matter," The Emergency (Detained Persons) Regulations 1954, s 14(2).

25. Eileen Fletcher resigned her post in charge of female "rehabilitation" facilities in Kenya after a mere 7 months, in protest over the conditions of detention, and she subsequently made statements to the press about what she had witnessed; see "Conditions in Kenya Detention Camps," The Times, June 7, 1956. Fletcher's claims were denied by the administration. The colonial secretary was deeply critical of Fletcher's allegations, "I am quite satisfied that Miss Fletcher's charges are based in the main on hearsay, on partisan opinion and personal prejudice. The negligible amount of criticism which could be levelled has proved to be wholly disproportionate to the impression that she has contrived to create. I would ask all fair-minded people to read carefully the documents in the Library of this House and to make up their own minds," see Hansard October 31, 1956, vol. 558, cc 
Disclosure, ${ }^{26}$ although corroborating the biographical narratives of former detainees, ${ }^{27}$ have the power to redress the historical silencing by elucidating the contemporary colonial attitude to detainee protest. ${ }^{28}$

A claim for "alleged torts of assault and battery and negligence" was submitted to the United Kingdom High Court by five elderly Kenyans (Ndiku Mutua and Others $v$ The Foreign and Commonwealth Office), in which the complainants alleged that they had been tortured and mistreated by "officers and soldiers of the Kenya police force, the Home Guard and/or the Kenya Regiment" while detained in British camps between 1954 and 1959. ${ }^{29}$ The injuries suffered by the former detainees resulted from "physical mistreatment of the most serious kind, including torture, rape, castration and severe beatings." 30 On the one hand, the British government rejected the argument that it had "through the Colonial Office and the Army (under General George Erskine), played a material part in the creation and maintenance of a system for the suppression of the rebellion, in part by means of torture and other mistreatment of detainees." 31 Onn the other hand, however, the British Foreign Secretary, William Hague, accepted the need for an examination of colonial era abuses. The case was fought tenaciously by the British government, which resorted to detailed technical

1418-21. See also TNA CO 822/1236: Memoranda prepared by the Colonial Office on reports by Eileen Fletcher on detention and imprisonment of children in Kenya, 1957.

26. The "Hanslope Disclosure," refers to the discovery in 2011 of more than 8,000 files pertaining to thirty-seven former colonies at a Foreign and Commonwealth Office building in Hanslope Park, Milton Keynes. Between April 2012 and November 2013, the majority of these files were released to the National Archives, Kew Gardens. Within the National Archives, the FCO 141 series is generally referred to as the "migrated archives."

27. Marshall S. Clough ed., Mau Mau Memoirs: History, Memory and Politics (London: Lynne Rienner Publishers, 1998); Gakaara wa Wanjaii, Mau Mau Author in Detention (Nairobi: Heinemann Kenya, 1988); Wambui Waiyaki Otieno, Mau Mau Daughter: A Life History (London: Lynne Rienner Publishers, 1998); and Josiah Mwangi Kariuki, "Mau Mau" Detainee: The Account by a Kenya African of His Experiences in Detention Camps, 1953-1960 (Transafrica Press, 2009).

28. For example, see the government's response to Victor Shuter's exposition of the brutality he witnessed in the Kenyan "rehabilitation" camps in Elkins, Imperial Reckoning, 340-44. Also, Huw Bennett notes that one settler (Denning) complained about screening teams beating up his employees. The authorities dismissed Denning's allegations, accusing

Q13 him of being a man with "a rather unsavoury past," Bennett, Fighting the Mau Mau, 37.

29. Ndiku Mutua and Others $v$ The Foreign and Commonwealth Office [2011] EWHC Q14 1913 (QB), July 21, 2011, para. 1; and Ndiku Mutua and Others $v$ The Foreign and Commonwealth Office [2012] EWHC 2678 (QB), November 5, 2012.

30. Ndiku Mutua and Others $v$ The Foreign and Commonwealth Office [2011], para. 1.

31. For more on the mechanisms involved in governmental denial of human rights abuses and atrocities see Stanley Cohen, States of Denial: Knowing About Atrocities and Suffering (Cambridge: Polity, 2001). 
arguments at an early stage of proceedings; a position described by Justice Q3 McCombe as "dishonourable," given the serious nature of torture. ${ }^{32}$ Therefore, the unexpected announcement by the foreign secretary in June 2013 that a settlement of $£ 19,900,000$ would be granted to 5,228 Kenyan camp survivors appears to have been a complete reversal of the government's position. ${ }^{33}$ It must be borne in mind that the settlement came after the British government had experienced a number of setbacks in court, and evidence of systematic and widespread abuses in detention was mounting as historians analyzed declassified files (the "Hanslope Disclosure") and other sources. ${ }^{34}$ Hague stressed, however, that the government was not accepting legal liability in the case, and he attempted to shut the door on prospective claims from other former colonies "[w]e continue to deny liability on behalf of the Government and British taxpayers today for the actions of the colonial administration in respect of the claims, and indeed the courts have made no finding of liability against the Government in this case. We do not believe that claims relating to events that occurred overseas outside direct British jurisdiction more than fifty years ago can be resolved satisfactorily through the courts without the testimony of key witnesses that is no longer available." 35 Aside from pointing out that the settlement was not precedent setting, Hague also vigorously defended the government's right to fight such claims. ${ }^{36}$

Pressure to locate missing colonial files stemmed directly from the Ndiku

Q4 Mutua and Others $v$ The Foreign and Commonwealth Office case. Historians, such as David Anderson, were aware that hundreds of valuable files had been transferred from Kenya to the United Kingdom prior to Kenyan independence in 1963. An inquiry was submitted to the relevant section of the FCO regardQ5 ing these missing files, but it was unsuccessful. Finally, on foot of a second request, in January 2011 an official within "the defendant's organisation received a telephone call from IMG [Information Management Group] indicating that what appeared to be the missing 300 boxes had been found. The defendant then set in train a process of analyzing the new papers and disclosing those that they perceived to be relevant to the claimants." ${ }^{37}$ Upon

32. Ndiku Mutua and Others v The Foreign and Commonwealth Office [2011], para. 154.

33. "Statement to Parliament on settlement of Mau Mau claims," Foreign Secretary William Hague, June 6, 2013, full text of speech available at https:/www.gov.uk/govern ment/news/statement-to-parliament-on-settlement-of-mau-mau-claims (April 18, 2015).

34. Caroline Elkins, "Britain has said sorry to the Mau Mau. The rest of the empire is still waiting," The Guardian, June 7, 2013 http://www.theguardian.com/commentisfree/2013/ jun/06/britain-maumau-empire-waiting (April 18, 2015).

35. Hague, "Statement to Parliament on settlement of Mau Mau claims."

36. Ibid.

37. Ndiku Mutua and Others v The Foreign and Commonwealth Office [2011], para. 32. 
examination, the "Hanslope Disclosure" (also referred to as the "migrated archives" within the British National Archives system), revealed the existence of 8,500 files pertaining to thirty-seven former colonies at a FCO building in Hanslope Park, Milton Keynes. The majority of these files have been released to the National Archives, Kew Gardens.

Considering Nazi concentration camps, Giorgio Agamben, rather than questioning "how crimes of such atrocity could be committed against human beings," regards it as more honest and useful "to investigate carefully the juridical procedures and deployments of power by which human beings could be so completely deprived of their rights and prerogatives that no acts committed against them could appear [...] as a crime." ${ }^{38}$ This question is relevant to a retrospective inquiry into Kenyan detention camp abuses. The crux of the matter is this: British politicians and colonial officials readily abandoned fundamental legal principles when the abrogation affected an "undesirable other." Amnesties, such as the one applied to Kenya, which pardoned all violence that had occurred prior to January 18,1955 , and ex post facto regulations, which legalized foregoing criminal acts, ${ }^{39}$ effectively gave the accountability deficit a façade of legality. The "self-preserving violence" of the state was shielded by impunity in government, which was also fostered by the judiciary, even where evidence existed that ill-treatment, torture, and unlawful killings had occurred in British custody. ${ }^{40}$

This entire system would have collapsed under the weight of normal investigatory standards and accountability; therefore, impunity upheld the restricted liberty conditions throughout the "emergency" and perpetuated a culture of violence. In framing the terms of decolonization, the British government also defined the historical narrative of the Mau Mau insurgency and the counterinsurgency. This discourse portrayed state violence as necessary and the British colonials as rational and legitimate actors. To no small extent, this was a reaction to the postwar atmosphere which supported anticolonial struggles and self-determination, ${ }^{41}$ sponsored by the United

38. Giorgio Agamben, Homo Sacer: Sovereign Power and Bare Life (Stanford, CA: Stanford University Press, 1998), 171

39. For example, the British colonial administration passed Regulation 27A in Malaya after the Batang Kali massacre in December 1948; see Mark Townsend, "Revealed: how Britain tried to legitimise Batang Kali massacre," The Guardian, May 6, 2012. http:/www.theguardian.com/ world/2012/may/06/britain-batang-kali-massacre-malaysia (April 18, 2015).

40. See, for example, Elizabeth Kolsky's study of white violence in colonial India: Colonial Justice in British India (Cambridge: Cambridge University Press, 2010).

41. Klose, Human Rights in Shadow of Colonial Violence, 199. See also Burke, Decolonization and the Evolution of International Human Rights, 39. 
States and enshrined in the United Nations Charter. ${ }^{42}$ Frederick Cooper identifies tensions that arose between American and British policy makers attempting to agree on a self-governing framework for African states. ${ }^{43}$ The Colonial Office was forced to present a "progressive colonial policy," promulgated in the Colonial Development and Welfare Act, which purportedly aimed to raise socioeconomic and labor standards of indigenous peoples preparing for self-government. ${ }^{44}$ Cooper argues that it did nothing of the sort, and highlights the colonial secretary's rationalization for maintaining the colonial status quo, "I am not basing my argument on material gains to ourselves, important as I think these may be. My feeling is that in these years to come without the Commonwealth and Empire, this country will play a small role in world affairs, and that here we have an opportunity which may never recur, at a cost which is not extravagant, of setting the Colonial Empire on lines of development which will keep it in close and loyal contact with us." 45 Moreover, the colonies had proven beneficial during the war, and the economic significance of these acquisitions extended as certain promises made to British consumers were to be redeemed after the war. ${ }^{46}$ Another factor that may have conversely pushed colonial era abuses underground is that the British government was heavily involved in drafting the European Convention on Human Rights, with Winston Churchill maintaining that the Strasbourg institutions "would exist to draw attention to violations of human rights through a ruling that represented a 'judgment of the civilized world'." ${ }^{47}$ The British jurist, Sir David Maxwell-Fyfe, is considered a founding father of the European Convention. ${ }^{48}$ In order to reconcile the dissonance between European Convention ideals and the actual situation in many colonies, the colonial administration had to hide evidence of abuses, and this created a culture of denial that has contemporary resonance. Consequently, a massive propaganda campaign was launched against Mau Mau, "one of the most intensive propaganda attacks on an African national movement," that sought to delegitimize the movement, while at the same time withholding details of

42. Following the United States Charter, a United Nations commission was tasked with drafting the Universal Declaration of Human Rights, which came into being in 1948.

43. Cooper, Decolonization and African Society, 112.

44. Colonial Development and Welfare Act 1940.

Q15 45. Cooper, Decolonization and African Society, 120, Cooper references TNA PREM 4/ 43A/8: WP (44)643.

46. Ibid., 123.

47. Winston Churchill quoted in Ed Bates, The Evolution of the European Convention on Human Rights: From its Inception to the Creation of a Permanent Court of Human Rights, (Oxford: Oxford University Press), 7.

48. Ibid., 61. 
colonial and administrative violence from public scrutiny. ${ }^{49}$ Fabian Klose describes the development of an "effective information machine" in Kenya, which underpinned military endeavors. He elucidates a two pronged British propaganda strategy, with the internal element directed toward manipulating public opinion within the colony, whereas the external strand, managed by the Kenya Government Press Office, "filtered information on the situation in the crown colony to the national and international media." ${ }^{\circ 0}$ An additional public relations hub was established in London, the Kenya Government Public Relations Office, which was "chiefly responsible for the international public image of the Kenya question." 51

This concern with appearance and concealing security force violence continued during decolonization, and within the Hanslope files it is possible to pinpoint significant directives issued by the Colonial Office in the late 1950s that were central to the framework of official denial and amnesia regarding the colonies. As British colonial territories were inching toward independence in the mid-twentieth century, the British government redoubled its efforts to bury any evidence that implicated its colonial officials in violations that occurred in territories under British administration. ${ }^{52}$ On the whole, there were two main sources of concern: international political disapprobation, and the consequence of litigation arising from a former colony. As a result, all top-secret classified materials were rapidly centralized in executive offices and marked for "European eyes only" prior to Kenyan independence, and the files were then either destroyed or removed to the United Kingdom in the 1960s..$^{53}$ It was intended that evidence of serious human rights abuses would be destroyed in these document purges. On December 9, 1959, a secret dispatch was sent from the Colonial Office in London to various colonial administrations regarding the "security of documents. $"{ }^{54}$ In essence, the circular granted authority to the governor to destroy any top secret or "accountable" material prior to the transfer of sovereignty to the independent territory. In addition, governors were obliged to destroy "any Top-Secret or Accountable document if requested

49. Wunyabari Maloba quoted in Klose, Human Rights in the Shadow of Colonial Violence, 199.

50. Ibid., 200.

51. Ibid.

52. Ian Cobain, Owen Bowcott, and Richard Norton-Taylor, "Britain destroyed records of colonial crimes," The Guardian, April 18, 2012 http://www.guardian.co.uk/uk/2012/apr/18/ britain-destroyed-records-colonial-crimes (April 18, 2015).

53. Ibid.

54. These administrations were Tanganyika, Singapore, Leeward and Windward Islands, and the East African High Commission, see TNA FCO 141/6957: Despatch signed by Lord Perth on behalf of the Colonial Secretary, December 9, 1959. 
to do so by the Secretary of State." ${ }^{55}$ To audit the process, the Colonial Office required the submission of annual returns regarding which "accountable" documents had been destroyed, and a list specifying "accountable" documents that remained in the colony. A "Destruction Certificate" was submitted to the colonial secretary when materials were destroyed, whereas a "Handing Over Certificate" was submitted for any documents transferred to a newly independent government. ${ }^{56}$

There were various permutations across the colonies in how the directive was applied and in Uganda, a memo entitled "Operation Legacy" was circulated in February 1961, with the instruction that official papers should be withdrawn ("either be destroyed or passed to a higher office") and made inaccessible to "unofficial" or "unauthorised officers." 57 Materials destined for this treatment were to be "known as 'DG' [Deputy Governor] papers." 58 It was imperative that the following files be included in the series: "any papers which might be interpreted as showing religious intolerance on the part of H.M.G., the present Uganda Government or friendly countries," and "all papers which might be interpreted as showing racial discrimination against Africans (or Negroes in the USA) on the part of H.M.G., the present Uganda Government or friendly countries." 59

In Kenya, sensitive materials were categorized as belonging to the "Watch" series, but for purposes similar to the "DG" categorization in Uganda. Overall, the "Watch" catalogue incorporated papers "which must only be seen by 'authorised' officers... And which will ultimately have either to be destroyed or to be removed to the United Kingdom." 60 Alternatively, documents could have been filed under the "Legacy" series, namely, "all those other papers which may safely and appropriately be seen in the course of duty by persons who may not fit the definition of 'authorised' officers, and which will eventually be inherited by an independent Government." 61 In the event, an "authorised" officer entitled to handle "Watch" materials was "a servant of the Kenya government who is a British subject of European descent." 62 Underpinning this administrative

55. TNA FCO 141/6957: Circular 1282/59, "Security of Documents," December 9, 1959, from Lord Perth on behalf of the secretary of state, para. vi.

56. Ibid., paras. ii, iii, vi.

57. TNA FCO 141/6957: Circular memorandum, “Operation Legacy,” February 28, 1961, para. 3 .

58. Ibid., para. 4.

59. TNA FCO 141/6957: Appendix to circular memorandum, "Operation Legacy," February 28, 1961, para. 1.

60. TNA FCO 141/6957: Undated draft entitled "The Designation Watch."

61. Ibid.

62. Ibid., para. 9. 
directive was the assumption that the new classification would exclude black Africans; therefore, it enabled "social exclusion without slippage into transparently racist language." 63 Reiterating the nomenclature of the Uganda circular (which was widely disseminated in Kenya), a Special Branch directive outlined that "[a]ll papers which might be interpreted as showing racial discrimination against Africans on the part of Q6 Government" must be included in the "Watch" series. ${ }^{64}$ Against this, it was essential that the existence of the series be concealed, and to minimize the risk of exposure, a Kenyan Ministry of Defence official advocated a restricted distribution list to provincial commissioners, permanent secretaries, and a small number of heads of departments. ${ }^{65}$

As the pace of localization quickened, the destruction and removal of "Watch" material continued apace. An illustration of potentially inculpatory documentation included the "personal secret and confidential files" of approximately 1000 "officers, particularly those of certain district officers, police officers, prison officers, ex-field intelligence officers," replete with information "which in the interests of those officers should not be retained in the Government Registries after independence." 66 It is notable that some "Watch" materials survived the end of empire document cull and are included in the Hanslope Disclosure. ${ }^{67}$ On the whole, the surviving Hanslope materials have been released to the National Archives, with some redactions. ${ }^{68}$ The new information documented in this article may

Q7 well be comprehended against the inscription of Kenyan peoples as subjects of British colonial law, and the constitutional arrangements in which an emergency detention regime would flourish without meaningful oversight mechanisms.

63. Christopher Lee, "Jus Soli and Jus Sanguinis in the Colonies: The Interwar Politics of Race, Culture, and Multiracial Legal Status in British Africa," Law and History Review 29 (2011): 507.

64. TNA FCO 141/6957: Measures for the Protection of Special Documents: Protection of Special Branch Material, use of the marking "Watch."

65. TNA FCO 141/6957: minute by Geoffrey Ellerton attached to Designation Watch Circular, para. 22.

66. TNA FCO 141/6957: letter from the Governor of Kenya to the colonial secretary with subject line "Security of Personal Records of Officers," September 21, 1961.

67. These documents may have been retained because of their historical importance, but a more likely explanation is that there was a lack of the requisite person-power needed to destroy such volumes of material in a relatively short time frame, see TNA FCO 141/ 6957-6959: these files contain numerous Watch documents all bearing the "W" stamp.

68. There may be further clues as to exactly which materials were destroyed. For example, the Colonial Office should have registries for the "Watch" series, copies of annual reports from each colony on "accountable" documents, and destruction certificates from various governors detailing the documents they had destroyed. 
69. The British government took over from the Imperial British East Africa Company, because it was unable to fulfil its charter obligations as a result of financial difficulties, see C. W. Hobley, Kenya from Chartered Company to Crown Colony (London: Frank Cass Publishers, 1929), 124.

70. Sandra Fullerton Joireman, "The Evolution of the Common Law: Legal Development in Kenya and India," Commonwealth \& Comparative Politics 44 (2006): 190-210, see also Brett Shadle, "'Changing Traditions to Meet Altering Conditions': Customary Law, African Courts and the Rejection of Codification in Kenya, 1930-60," The Journal of African History 40 (1999): 411-31.

Q13 71. Anghie, Imperialism, Sovereignty, 105.

72. Henry Morris, Government Publications relating to Kenya (including the East Africa High Commission and the East African Common Services Organisation) 1897-1963 (London: School of Oriental \& African Studies, University of London, 1976), see http:// www.microform.co.uk/guides/R96995.pdf (April 18, 2015).

73. Anderson, Histories of the Hanged, 29.

74. Berman, "Bureacracy and Incumbent Violence," 145, 153. 


\section{British Settlement Act 1887}

In 1920, the East African Protectorate was annexed by the Kenya (Annexation) Order in Council (June 11, 1920), under Section 2 of the British Settlement Act $1887,{ }^{75}$ to create the colony of Kenya. ${ }^{76}$ The British Settlement Act further enabled the Crown by Letters Patent or a similar instrument "to delegate to any three or more persons within the settlement" the powers conferred by Parliament. ${ }^{77}$ A Letters Patent (1920) fleshed out details of the new colony's governmental institutions. ${ }^{78}$ Article 1 set out the Office of the Governor General, whereas Article 3 conferred powers on the Governor General's Office, provided these were not repugnant to other provisions of the Letters Patent. Lawmaking powers passed to the Legislative Council; provisions and regulations were to correspond to the laws of England and local lawmaking powers were delegated such as were "necessary for the peace, order, and good government of the Colony."79 The governor had the power to veto legislation drafted by the Legislative Council, and a subsequent document affirmed the status of the governor as the "single and supreme authority responsible to, and representative of, Her Majesty," and, therefore, entitled to the aid and assistance of military and civilian servants within the Colony. ${ }^{80}$ It was through this office that emergency powers, such as executive detention and warrantless arrest, were realized.

\section{Emergency Laws and Detention Ordinances}

Following an upsurge in violence against settler farmers and the assassination of the Paramount Chief for Central Province, Chief Waruhiu, on October 7, 1952, ${ }^{81}$ the Governor of Kenya, Sir Evelyn Baring, declared

75. Section 2 outlines that "[i]t shall be lawful for her Majesty the Queen in Council from time to time to establish any such laws and institutions, and constitute such courts and offices, make provisions and regulations for the proceedings in the said courts and for the administration of justice, as shall appear to Her Majesty to be necessary for the peace, order and good government of Her Majesty's subjects and others within any British settlement," The British Settlement Act 1887, s. 2.

76. The Kenya (Annexation) Order June 11, 1920.

Q13 77. Roberts-Wray, "Commonwealth and Colonial Law," 168.

78. Letters Patent of September 11, 1920. The 1920 Letters Patent were "repealed by the Kenya Constitution Order 1958, Section 1(3) and the First Schedule. However, Section 3 of the 1958 Constitution re-produced a statement of the powers and duties of the governor in closely similar terms to Article 3 of the old instrument," see Ndiku Mutua and Others v The Foreign and Commonwealth Office [2011], para. 23.

79. Letters Patent of September 11, 1920, s. 10

80. Directions for a General Guidance to Colonial Governors, Colonial Regulations, 1956.

81. Klose, Human Rights in the Shadow of Colonial Violence, 70. 
a state of emergency in the territory on October 20, 1952, which lasted until January 12, $1960 .^{82}$ It is notable that the wartime Emergency Powers Order-in-Council 1939 was invoked, ${ }^{83}$ which provided the governor with complete discretion to introduce any regulation he thought "necessary or expedient for securing the public safety, the defence of the territory, the maintenance of public order and the suppression of mutiny, rebellion and riot, and for maintaining supplies and services essential to the life of the community." ${ }^{4}$ Notwithstanding these general powers, $6(2)(a)$ of the order specified that the regulations could "make provision for the detention of persons and the deportation and exclusion of persons from the territory." ${ }^{85}$ It was on this authority that the governor passed a number of detention ordinances during the 1950 s, providing the legal basis for the incarceration of Mau Mau suspects without trial. ${ }^{86}$ According to a Colonial Office memorandum, "the Governor may make a detention order against any person over whom he is satisfied that it is necessary to exercise control for the purpose of maintaining public order." 87

82. Political authorisation for the proclamation had been given by resolution of the United Kingdom Cabinet of October 14, 1952, see Ndiku Mutua and Others $v$ The Foreign and Commonwealth Office [2011], para. 8. Proclamation reads as follows: "IN EXERCISE of the powers conferred on me by section 3 of the Emergency Powers Order in Council, 1939, and of all other powers enabling me in that behalf, I DO by this Proclamation bring into operation the provisions of Part II of the said Order in Council with effect from the date of this Proclamation," The Emergency Powers Order in Council, 1939, Proclamation No. 38 of 1952.

83. "His Majesty, by virtue and in exercise of the powers vested in Him by the British Settlements Act, 1887, the Foreign Jurisdiction Act, 1890, and of all other powers enabling Him in his behalf, is pleased, by and with the advice of His Privy Council, to order, and it is hereby ordered, as follows: 3 . The provisions of Part II of this Order shall have effect in any territory in which they shall from time to time, in case of any public Emergency, be brought into operation by Proclamation made by the Governor, and shall continue in operation until a further Proclamation directing that they shall cease to have effect is made by the Governor, and shall then cease to have effect except as respects things previously done or omitted to be done." The Emergency Powers Order in Council, 1939, part I, s. 3.

84. The Emergency Powers Order in Council, 1939, March 9, 1939, Part II - Regulations, s. $6(1)$.

85. Ibid., s. 6(2)(a).

86. The governor passed the first emergency regulation pertaining to detention in 1952 drawing from powers contained in Section 3, part 2, 6 (2) (a) of the Emergency Powers Order-in-Council, 1939, which conferred upon the governor of Kenya powers to detain individuals in an emergency context. The 1939 Order-in-Council was replaced by the Emergency Powers (Amendment) Order-in-Council 1952 to deal with the exigencies of the colonial situation, see TNA CO 822/725. Detention ordinances included: Emergency Regulations 1952, Detention Orders and Power to Detain Suspected Persons; The Emergency (Detained Persons) Regulations 1954; The Emergency (Detention Camps) Regulations 1959.

87. TNA CO 822/725: Note on detainees in Kenya, Colonial Office. 
Detention without trial became a cornerstone of counterinsurgency operations in Kenya and enemy suspects were held in facilities ranging from detention camps to Home Guard stations, screening centers, transit camps, and makeshift units on white settler farms. ${ }^{88}$

As it turns out, detention regulations were ratified on the same day that the emergency was proclaimed. Section 2(1) of the Emergency Regulations 1952 read "[w]henever the Governor is satisfied that, for the purpose of maintaining public order, it is necessary to exercise control over any person, the Governor may make an order (hereinafter called a detention order) against any such person directing that he be detained, and thereupon such person shall be arrested and detained." 89 Operation Jock Scott was launched in Nairobi the following day, during which 180 alleged Mau Mau leaders were arrested, including the moderate politician, Jomo Kenyatta, who was a central figure in the Kenya African Union. ${ }^{90}$ Kenyatta disavowed Mau Mau violence, but was sentenced to 7 years' imprisonment, after what was considered a highly politicized trial and he "thus became a martyr of the movement." 11 Operation Anvil, launched on April 16, 1954, ${ }^{92}$ gave rise to a new wave of arrests, and by December 1954, 71,346 Mau Mau suspects were being detained in camps across Kenya. ${ }^{93}$ In Kenya and in Britain, the detention camps were promoted as places of rehabilitation, so as to relieve the Kikuyu of

88. Anderson, Histories of the Hanged, 5.

89. Emergency Regulations 1952, s. 2(1).

90. Klose, Human Rights in the Shadow of Colonial Violence, 70.

91. Ibid. See also Montago Slater, The Trial of Jomo Kenyatta (London: Secker \& Warburg, 1955). Although the administration went through the motions of a trial process for Kenyatta, he and many others were to languish in appalling camp conditions for the duration of the emergency. See John Lonsdale, "Kenyatta's trials: breaking and making an African nationalist," in The Moral World of the Law, ed. Peter Coss (Cambridge: Cambridge University Press, 2000), 196-239. Kenyatta went on to become Kenya's first president at independence; see also, Jomo Kenyatta, Suffering without Bitterness. The Founding of the Kenya Nation (Nairobi: East African Publishing House, 1968); and Jomo Kenyatta, Facing Mount Kenya: The Traditional Life of the Gikuyu (London: Heinemann, 1979).

92. Caroline Elkins observes that 16,500 were detained in Nairobi during Operation Anvil, Ndiku Mutua and Others $v$ The Foreign and Commonwealth Office [2011], para. 42. Cooper points out that during Operation Anvil all Kikuyu inhabitants living in Nairobi were detained, purely on the basis of ethnicity, and that this led to a labor shortage in the city, see Decolonization and African Society, 355. However, Klose maintains that half of Kikuyu inhabitants in Nairobi were detained following Operation Anvil, whereas the other half (mainly women and children) were returned to the (already overpopulated) reservations, Human Rights in the Shadow of Colonial Violence, 75.

93. Anderson, Histories of the Hanged, 313. 
their Mau Mau "psychopathology." 94 Essentially, however, the camps were sites of intelligence gathering underpinned by abusive methods, sites of cheap or free labor, and locations where sovereign power atomized communities, families, and villages in the production of dehumanized individuals or to borrow Giorgio Agamben's phrase, homo sacer, an allegorical figure from Roman history who could be killed without the commission of homicide. ${ }^{95}$ Emergency codes and ordinances merely gave the violent architecture a façade of legality.

In her study on the history of confinement in Africa, Bernault argues that the colonial penitentiary merely supplemented the "public violence" endemic to African colonial societies. ${ }^{96}$ Corporal punishment as a penal sanction was abolished in England and Wales in 1948, and shortly afterwards, the Colonial Secretary, James Griffiths, announced that the colonies should follow suit. ${ }^{97}$ However, "in the 1950s, sentences of corporal punishment increased in [...] Kenya." 98 A detailed punishment regime prescribed by detention regulations was applied within the Kenyan camps. Minor offenses were punishable by one or more of the following: solitary confinement and reduced diet, removal of privileges, and reprimand. ${ }^{99} \mathrm{~A}$ similar punishment regime could be invoked for major offenses, such as mutiny, assault on a prison worker, or aggravated assault on another detainee, and these could also attract corporal punishment. Regulation 17 of the Emergency (Detained Persons) Regulations 1954 stipulated that corporal punishment should not exceed twelve strokes and that the officer-in-charge of the camp was to be present while the punishment was being executed. ${ }^{100}$ In their edited volume, Discipline and the Other Body, Anupama Rao and Steven Pierce argue that colonial "corporeal violence," such as flogging, bodily violence and torture, was applied to individuals or "bodies" increasingly deemed irrational, even as they "simultaneously emerged as [...]

94. Pierce and Rao, Discipline and the Other Body, 1. The Kenyan administration commissioned Dr. John Carothers to write a report, one of the sole surviving examples of government sponsored "ethno-psychiatry," purportedly to help understand the causes of the Mau Mau rebellion; see John Carothers, The Psychology of Mau Mau (Nairobi: Government Press, 1954); see also TNA FCO 141/5666: Athi River Rehabilitation Camp -undated memorandum circa August 1953.

95. See Agamben, Homo Sacer. See also Aoife Duffy, "Detainee as "Exile": Theorizing the Politico-Legal Underpinnings of Executive Detention," Interdisciplinary Journal of Human Rights Law 7 (2012-2013): 1-17.

96. Bernault, A History of Prison and Confinement in Africa, 3.

97. Ibid., 109.

98. Ibid., 109-10.

99. Minor offences included, inter alia, spitting, malingering, refusing to eat, and making excessive noise, the Emergency (Detained Persons) Regulations 1954, s. 17.

100. Ibid., s. 17(a). 
targets of humanitarian reform."101 This pattern was evident during the Kenyan Emergency, whereby the use of corporal punishment proliferated with the introduction of Mau Mau detainees into what Daniel Branch terms the "carceral archipelago;" 102 however, it was conversely underpinned by Christian concern for these damaged subjects. In particular, an experiment was launched at Athi River Rehabilitation Camp by the Moral Rearmament Army (MRA), which offered "Christian and democratic alternatives" to the Mau Mau "disease of the mind," with the promise of curing "thousands of KEM [Kikuyu] now infected" and demolishing "their present faith" to substitute it with "a superior one." 103

Substantively, there were two means through which detainees could challenge the basis of detention. First, every detainee had the right to make a representation in writing to the governor in respect of his or her detention order. ${ }^{104}$ As the population was largely illiterate, this made access to justice difficult, and it is unclear from the surviving records how many detention orders were revoked as a result of these petitions. A

Q3 three person "Advisory Committee on Detainees" chaired by Justice C.P. Connell was established in 1953 to review detainee appeals. ${ }^{105}$ It was the chairman's duty to "inform the objector of the grounds on which the order [had] been made against him and to furnish him with such particulars as are, in the opinion of the chairman, sufficient to enable him to present his case." 106 Detainees were not entitled to legal representation before the Committee, and only received a summary of the charges in advance, with more detail being provided during the oral hearing. As such, the Advisory Committee was not a judicial fact-finding body, but had a mandate to assess the risk that a detainee posed to public security if released. Caroline Elkins maintains that fewer than 250 appellants secured their freedom through this procedure, but a letter dated January 4, 1960 from the Colonial Secretary Iain Macleod to Dingle Foot, MP outlines the number of appeals made to the Advisory Committee during the emergency and out of 2,604 submissions, 1,088 were successful, representing a $41 \%$

101. Pierce and Rao, Discipline and the Other Body, 6.

102. Corporal punishment constituted $17 \%$ of penalties for personal violence offenses in 1938 , but this rose to $61 \%$ by 1951 ; see Daniel Branch, "Imprisonment and Colonialism in Kenya, C. 1930-1952: Escaping the Carceral Archipelago," International Journal of African Historical Studies 38 (2005): 256.

103. TNA FCO 141/5670: Working Party on Future of Athi River Detention Camp, May 11, 1955, various government ministers were in attendance.

104. Emergency Regulations, 1952, s. 2(3)(b).

105. Ibid., s. 2(3)(c).

106. TNA CO 822/1234: letter from Dingle Foot to John Profumo, November 25, 1957. 
success rate. ${ }^{107}$ Detainees were not immediately released following the Advisory Committee's recommendations, but passed up through the "pipeline" to "open camps" for eventual reintegration into the community. ${ }^{108}$ Although the recommendations were not binding upon the governor, in a letter to the secretary of state for the colonies, Governor Baring asserted that he had never overruled a decision made by the Committee. ${ }^{109}$

\section{Violence in the Detention Archipelago}

The emergency was a time of violent upheaval in certain regions of Kenya, notably in the Rift Valley and Central Provinces, and none were more affected by violence than the Kikuyu population, who were, in general, deemed untrustworthy by the administration and as potential Mau Mau accomplices. ${ }^{110}$ The Kikuyu experienced "undesirable atrocities and tortures" in their contact with the security forces and the Kenya Regiment. ${ }^{111}$ Composed of several battalions, the territorial Kenya Regiment was staffed by British army officers, whereas the rank and file were mainly European settlers. It adhered to the normal army chain of command. By March 1953, Home Guards units composed of loyalist Kikuyu, Meru, and Embu had been formed. ${ }^{112}$ Huw Bennett submits that the role of the Home Guard evolved over time, and whereas initially they were charged with protecting village chiefs and headmen, in 1953, "units began to patrol large areas and fight in combat." 113 Home Guard posts were fortified buildings located in the new villages, ${ }^{114}$ which became increasingly implicated in violence as

107. TNA CO 822/1234: letter from Ian Macloed, Colonial Secretary, to Dingle Foot, January 4,1960.

108. Elkins, Imperial Reckoning, 111, 120, 237.

109. TNA CO 822/1234: letter from Governor Baring to the secretary of state for the colonies, June 24, 1958.

110. Bennett, Fighting the Mau Mau, 8.

111. TNA FCO 141/5667: A petition from more than 1,000 detainees, Athi River Internment Camp to all party Parliamentary delegation, c/o Government House, Nairobi, January 20, 1954.

112. The Embu and Meru people were closely linked to the Kikuyu tribe and also targeted by emergency regulations.

113. Bennett, Fighting the Mau Mau, 16.

114. Villagization was a counterinsurgency strategy adopted in Malaya, and transposed to the Kikuyu reserves, where it was portrayed as a security measure designed to protect the Kikuyu population from Mau Mau "infection;" see Carothers, "The Psychology of Mau Mau," 20. See also TNA FCO 141/5666 for a detailed report on detention and rehabilitation in Malaya, compiled by the Community Development Organisation following a visit to Malaya, with recommendations for Kenya, August 27, 1953. The creation of these new villages was "an unprecedented opportunity for the introduction of liberal reform and British 
the emergency unfolded. ${ }^{115}$ By 1955, approximately 800 Kikuyu "new villages" had been established through the forcible relocation of more than $1,000,000$ Kikuyu living throughout the Kikuyu reserves. ${ }^{116}$ A petition from "more than 1,000 detainees" who were being held at the Athi River Internment Camp alludes to the violent destruction of Kikuyu homesteads by the British Army. ${ }^{117}$ Homes were burned to the ground, leaving families destitute, while under-aged girls "were raped by [...] unscrupulous members of the KAR [King's African Rifles] $]^{118}$ and Home Guards." 119 Following arrest, detainees held in police cells and barbed wire encampments on the reserves were tortured by the police, security forces, or members of the Kenya Regiment. ${ }^{120}$ This brutality included the "castration of men by beating the sexual organs or by electrifying," and one of the Mutua and Others claimants, Paulo Muoka Nzili, was castrated while detained at the Embakasi detention center in 1957.121 As noted in the Athi River petition, Mau Mau suspects were hung upside-down by their ankles for days on end, and their money, livestock, property, motor vehicles, and other possessions were confiscated. ${ }^{122}$ At the same time, neighbors with petty grievances took the opportunity to settle old scores, and accused fellow residents of being Mau Mau adherents, inviting their neighbors' arrest, detention and disenfranchisement.

Life in the camps was severe, which is illuminated by letters smuggled out of detention facilities. A letter of protest from "more than 2,000 detainees" incarcerated on Mageta Island in Lake Victoria describes unsanitary living conditions, whereby detainees were not allocated soap for personal hygiene. On Mageta Island there were no professional health workers, whereas at Athi River Rehabilitation Camp, which had a medical officer,

civilising values" according to one influential settler; see Elkins, Imperial Reckoning, 236. The strategy's true purpose was to destroy the supply lines issuing from bases of Kikuyu support to active Mau Mau fighters, and Elkins believes that the villages were "detention camps all but in name," and were punitive in nature, 237.

115. Bennett notes that there were 18,000 Home Guards in Central Province, Fighting the Mau Mau, 13, 16.

116. Ndiku Mutua and Others $v$ The Foreign and Commonwealth Office [2011], para. 42.

117. The petition dates from January 1954.

118. The King's African Rifles was a battalion of the territorial Kenya Regiment.

119. TNA FCO 141/5667: A petition from more than 1,000 detainees, Athi River Internment Camp to all party Parliamentary delegation, c/o Government House, Nairobi, January 20, 1954. See also David Anderson and Julianne Weis, "Rape as a weapon of Q16 war? Sexual violence in Mau Mau Kenya," Law and History Review (forthcoming).

120. Ibid.

121. Ibid., and see Ndiku Mutua and Others v The Foreign and Commonwealth Office [2012], para. 37.

122. Ibid. 
medical negligence allegedly led to the death of Stephen Kiunjuri, whose raging fever was dismissed as "malingering." 123 Similarly, two detainees involved in a motor accident on Mageta Island were left without medical treatment for several days. ${ }^{124}$ In contravention of the basic safeguards set out by Regulation 17, floggings occurred in the absence of medical supervision. ${ }^{125}$ Three separate petitions testified to a culture within the camps of casual beatings where "ribs, legs and arms" were targeted by camp officers and warders. ${ }^{126}$ On Saiyusi Island Camp, warders used "clubs and sticks, knives and whips" against detainees, and the petition urged the administration to send an investigation team, so that detainees could show investigators the "wounds, bruises and teeth cracks" that they acquired as a result of beatings. ${ }^{127}$ These petitions were ineffectual because violence was authorized by the colonial administration and associated with government sanctioned detention policies, including, "screening," "dilution," forced labor, and the "Mwea procedure," discussed subsequently.

\section{Screening}

Screening was a procedure organized by the district administration, working with the British army, the Kenyan police reserves, loyalist chiefs, and the Special Branch, through which entire villages were rounded up into cordoned off enclosures and "screened;" in other words, questioned by a screening team (usually the local police), who used the information for a variety of purposes, including to arrest the "interrogatee." 128 The common denominator across permutations of "screening" was "the extraction of information from suspects." 129 As such, screening was founded on the assumption that "everyone was guilty until proved innocent."130 To that end, startlingly high arrest rates were achieved by some screening teams;

123. TNA FCO 141/5671: Letter from more than 2,000 detainees, Mageta Island to Argwings Kodhek, November 20, 1956. TNA FCO 141/5667: A petition from more than 1,000 detainees, Athi River Internment Camp to all party Parliamentary delegation, c/o Government House, Nairobi, January 20, 1954.

124. TNA FCO 141/5671: letter from more than 2,000 detainees, Mageta Island to Argwings Kodhek, November 20, 1956.

125. Bennett also refers to the security forces flogging Mau Mau suspects in "Fighting the Mau Mau," 161.

126. TNA FCO 141/5671: letter from more than 2,000 detainees, Mageta Island to Argwings Kodhek, November 20, 1956.

127. TNA FCO 141/5667: letter from Saiyusi Island Camp, petition to the chief secretary Nairobi, January 22, 1956.

128. For more on screening, see Elkins, Imperial Reckoning, 76-90.

129. Bennett, Fighting the Mau Mau, 15.

130. Ibid., 162. 
for example, $87 \%$ of 3,800 suspects screened in Nanyuki were subsequently arrested. ${ }^{131}$ In mid-1954, a massive screening operation dubbed "Operation Rat Catcher" was launched in Nairobi, which resulted in 17,000 individuals being screened. ${ }^{132}$ Screening also formed an important cornerstone of the confessional system that operated within the detention camps. As mentioned, it was imperative for detainees to make full confessions in order to progress through the rehabilitative "pipeline" that buttressed the network of camps.

Klose notes that British counterinsurgency techniques of this period depended on "systematic mass torture to extract information about the covert operation of the enemy," and that all available means were operationalised in the "battle for information." 133 Klose highlights some of the methods of violence utilized during screening and interrogation in Kenya. ${ }^{134}$ The death of Kabebe Macharia on September 15, 1958 occurred as a consequence of an "extremely severe" beating at the hands of two Embu screeners. ${ }^{135}$ Following Macharia's interrogation, he was removed to the camp dispensary where he died later that evening. A postmortem revealed the cause of death, and the two screeners were subsequently arrested and charged with murder. Ahead of the trial, the governor conceded that "it seems clear that brutality was used" against Macharia. ${ }^{136}$ It was, therefore, important that rehabilitation staff were sent the message that government "will not tolerate improper methods and where these occur the most rigorous action will be taken to punish offenders." 137 No European officer was present during the screening, and transcripts of the disciplinary proceedings suggested that it was "uncivilized African assistants" who were solely responsible for the murder. ${ }^{138}$ The two accused were charged with murder, but found guilty of manslaughter and sentenced to 3 years' imprisonment. 139

Q6 Against this and indicative of the racialization of justice, in 1953, two European officers responsible for the death of Elijah Gideon Njeru "were aquitted of manslaughter and only fined fifty and one hundred pounds, respectively, for battery." 140

131. Ibid., 163.

132. Ibid., 21.

133. Klose, Human Rights in the Shadow of Colonial Violence, 173.

134. Ibid., 173-78.

135. Elkins, Imperial Reckoning, 339-40.

136. TNA FCO 141/6332: draft telegram from the governor (undated).

137. Ibid.

138. Even though, as Elkins points out, it is likely that the officer in charge, Hugh Galton-Fenzi, who was physically present elsewhere in the compound, heard Macharia's screams during interrogation, Elkins, Imperial Reckoning, 340.

139. Ibid.

140. Klose, Human Rights in the Shadow of Colonial Violence, 176. 
A judgment from 1954 noted with concern that there was evidence that the defendants had been subjected to torture during screening "[f]rom this case and others that have come to our notice it seems that it may be a common practice when a person is arrested in the commission of a terrorist offence, or on suspicion of such offence, for the police to hand him over to the custody of one of these teams where, if the accounts given are true, he is subjected to a 'softening up' process, with the object of obtaining information from him." 141 In short, the judge disclaimed confessions extracted by "unlawful violence," and although several branches of the colonial administration denied responsibility for screening teams, the court found that "such methods are the negation of the rule of law which it is the duty of courts to uphold, and when instances come before the courts of allegations that prisoners have been subjected to unlawful criminal violence, it is the duty of such courts to insist on the fullest enquiry with a view to their verification or refutation."142

Klose highlights the exemplary prosecution and conviction of a British

Q3 army captain, G.S.L. Griffith, who offered incentives to his soldiers for killing Mau Mau, and had "verifiably tortured then executed prisoners," however, as Klose observes, brutality during interrogation and detention continued unabated. ${ }^{143}$ In response to persistent allegations, an Inquiry into Screening Camps and Interrogation Centres was launched in 1954. Sir Vincent Glenday, who chaired the inquiry, interpreted his terms of reference narrowly, as signifying the creation of prospective recommendations, rather than a retrospective examination of the allegations that had already come to light. Glenday completely overlooked the violence of screening when he described it as "a process to obtain or extract a confession by intensive interrogation from a multiple of facts and based on a promise of clemency if the confession be judged full and a veiled threat of reprisal if it be not so considered. To avoid any possible misinterpretation of this I should explain that whereas in the beginning considerable and often undesirable pressure was applied in some Camps, to-day it has generally been reduced to what is terms 'the psychological fear of being arrested and taken to the Camp as a detainee'." 144 Glenday assumed that screening was successful because of efficacious threats and psychological

141. Criminal Appeals 988 and 989 of 1954 (from Emergency Assize Criminal Case No. 584 of 1954 of HM Supreme Court of Kenya at Nairobi), Kenya National Archives (hereafter KNA): MLA 1/1098, cited in Ndiku Mutua and Others $v$ The Foreign and Commonwealth Office [2011], para. 126.

142. Ibid.

143. Klose, Human Rights in the Shadow of Colonial Violence, 178.

144. TNA FCO 141/6521: "An Inquiry into Screening Camps and Interrogation Centres under the Control of the Provincial Administration," (The Glenday Report), 1954. 
pressure, but even the Commander-in-Chief of the British Army in Kenya, General George Erskine, recognized that it was a violent process, "I am quite certain prisoners were beaten to extract information." 145 Invoking the diseased mind thesis, Glenday reported that "our Screening Camps are now mainly used for redemption or cleansing purposes so that a contaminated person may once again be accepted by his people as clear and ready to assist the Government if called upon to do so."146 Steering clear of any evidence that testified to the violence of screening, Glenday largely supported the procedure, although he questioned the validity of "re-screening," which entailed repeated screenings (one detainee could be screened three or four times), while accepting its purported cathartic effects. Screening continued and in a letter to Governor Baring dated November 1954, the Chief of Police, Colonel Arthur Young, ${ }^{147}$ highlighted the horrors of "some of the so-called Screening Camps which... how present a state of affairs so deplorable that they should be investigated without delay." 148 Young suggested that "elementary principles of justice and humanity" were not being observed in these camps; however, his criticisms were unacknowledged. ${ }^{149}$

\section{Dilution}

"Dilution" was a technique whereby a small number of "hard-core incorrigibles" were housed with cooperating detainees, who were tasked with "convincing" the noncooperating detainees to accept the "rehabilitative" regime of the works camp and to confess their Mau Mau activities. ${ }^{150}$ In the surviving records, the first reference to its usage is in May 1956, when a rehabilitation officer, Major James Breckenridge, wrote to senior officers at the Gathigiriri camp, drawing attention to an allegation that "Jasiel Njau [a rehabilitation assistant] had been putting detainees in the cells for refusing to confess to their Mau Mau activities and that he had either beaten them himself or instructed Warders to do so." ${ }^{151}$ Matters

145. TNA WO 32/15834: letter from Erskine to the secretary of state for war, December $10,1953$.

146. TNA FCO 141/6521: The Glenday Report, 1954.

147. For more detail on Colonel's Young position in relation to detention violence, see Q18 s. 3 below.

148. Klose, Human Rights in the Shadow of Colonial Violence, 179.

149. Ibid.

Q19 150. TNA FCO 141/6301: letter from Governor Baring to MCD regarding the death of detainee called Muchiri at Gathigiriri Works Camp, February 4, 1957.

151. TNA FCO 141/6301: Thomas Askwith, on behalf of the minister for community development to the attorney-general, February 11, 1957. 
came to a head when a detainee, Muchiri Githuma, succumbed to the violence meted out by Njau and a number of "cooperating" detainees on January $25,1957 . .^{152}$ Initially charged with murder, Njau and the detainees were later convicted of assault causing actual bodily harm, ${ }^{153}$ and the event was portrayed as "an isolated incident" stemming from "the excessive and misguided zeal of the Rehabilitation Assistant."154

Thomas Askwith, the Secretary of Community Development and Rehabilitation, wrote to the attorney-general in consideration of the Githuma case, calling attention to a previous complaint raised by Major Breckenridge regarding the camp's Community Development Officer, Q3 C.G. Hirst, and the officer in charge of Gathigiriri, Commander Q3 Rowe. ${ }^{155}$ Writing to the colonial secretary, the governor indicated that Hirst was directly involved in the Githuma case, as he did not attempt to stop the improper use of force. Hirst admitted that after Githuma "had been revived from unconsciousness," he forced Githuma to "run up and down pursued by another detainee with a rubber strap shortly before he finally collapsed and died." 156 The attorney-general advised Governor Baring that no criminal charges could be supported by the evidence against Hirst and Rowe, but that "disciplinary proceedings. .. are being considered."157

As a method of dilution, sometimes "a bucket of water [was] thrown at the man," which acted as "a form of shock treatment," and had a "most salutary effect." 158 On one occasion, a detainee, Kariuki Muriithi, died from hypothermia following water "shock treatment" during an attempted conversion at Athi River Detention Camp on July 18, 1957.159 The coroner revealed that Muriithi had died from exposure to the cold, and seven detainees were charged with manslaughter. The accused informed the court

152. TNA FCO 141/6301: letter from Governor Baring to the minister for community development regarding the death of detainee called Muchiri at Gathigiriri Works Camp, February 4, 1957.

153. Elkins, Imperial Reckoning, 333.

Q3 154. TNA FCO 141/6301: B.A. Ohanga, Minister for Community Development letter to Baring, February 7, 1957.

155. TNA FCO 141/6301: Askwith correspondence to the attorney-general, February 11, 1957.

156. TNA FCO 141/6301: from the governor to the secretary of state for the colonies, March 21, 1957. On another occasion, Hirst discovered a detainee hanging upside-down by his ankles, and although he ordered his staff to cut the detainee down, he took no further action, Ibid.

157. Ibid., and see TNA CO 1017/535: C.G. Hirst, Community Development Officer, Kenya: termination of contract, 1955.

158. TNA FCO 141/6301: undated memorandum on the rehabilitation of "Zs" by an unnamed government ministry.

159. FCO 141/6304: judgment of seven men charged with manslaughter of Kariuki Muriithi, July 18, 1957. 
Q3 Breckenbridge, the Camp Rehabilitation Officer. Breckenridge admitted authorizing detainees to sprinkle water on the detainee's face if he appeared to be falling asleep. The judge deemed the authorization to be unfortunate, but no charges were preferred against the British officers. Although following orders was not a valid defense in law, the judge concluded that it was as a mitigating factor, and in judgment, six of the accused were found guilty and sentenced to 1 month's imprisonment. ${ }^{160}$

\section{The Mwea Procedure}

Writing to the colonial secretary on June 25, 1957, Governor Baring commented on the "very hopeful results" that were being achieved from the dilution technique, but noted that in its application on a "small number of very difficult men[...] risks are unavoidable." 161 Apart from the Githuma killing, other incidents, such as a riot at Athi River Camp, had slowed down the progression of detainees through the "pipeline," and to overcome these difficulties an administrative officer, Terry Gavaghan, introduced a modified dilution procedure, known as the "Mwea technique." By this method, "hard-core" detainees arriving from Manyani camp were brought from the station in batches of twenty, with each group staggered at 15 minute intervals. Cooperating detainees accompanied the new intakes at a ratio of 10 to 1 , and all steps "to deal with refractory detainees" were to be taken by staff instead of cooperating detainees. Although some success had been achieved in securing detainee compliance, Baring considered that additional regulatory powers were required. To this end, he explained:

The resistance of these men breaks down quickly in the great majority of cases under a form of psychological shock... Gavaghan has been perfectly open with us. He has said that he can stop secret beatings such as that which occurred in the case of Jasiel Njau. He has said that he can cope with a regular flow in of Manyani "Zs" and turn them out later to the district camps. We believe that he will be able to go on doing this a very long way down the list of the worst detainees. But he can only do it if the hard cases are dealt with on their first arrival in a rough way. We have instituted careful safeguards, a medical examination before and after the arrival of the intake, the presence of the officer in charge all the time, the force being used by European staff only. ${ }^{162}$

160. Ibid.

161. FCO 141/6303: letter from Governor Baring to the colonial secretary, dated June 25, 1957.

162. Ibid. 
Either the whole procedure crafted by Gavaghan must be abandoned, argued Governor Baring, or "alternatively, we must give him and his staff cover provided they do as they say they are doing." 163 In consequence, the Attorney-General, Eric Griffith-Jones, drafted a detailed memo outlining the Mwea procedure, and drafted a regulation to cover the violence planned under the scheme. Undoubtedly, this legally dubious framework gave the colonial secretary cause for concern. ${ }^{164} \mathrm{~A}$ draft memo in the Hanslope files refers to a ministerial visit to the Mwea camp; the visiting party included the attorney-general, the minister for African affairs, the minister for community development, the special commissioner (C.M. Johnston), the commissioner of prisons, the acting secretary for defence, and the district commissioner of Embu, and the party witnessed at first hand the Mwea intake procedure. ${ }^{165}$ Gavaghan accompanied the party, explaining the full particulars of the operation. ${ }^{166}$ After the new arrivals were hustled off the trucks by European prison and rehabilitation staff and through a barbed wire cul-de-sac catwalk:

The detainees were ordered to squat in two rows, one at each said of the catwalk. The "receptionists" from the last intake then handed out the camp clothing to each man and set about shaving their heads with the hair clippers and razors, talking to the new arrivals as they did so. The detainees were ordered to change into the camp clothing. Any who showed any reluctance or hesitation to do so were hit with fists and/or slapped with the open hand. This was usually enough to dispel any disposition to disobey the order to change. In some cases, however, defiance was more obstinate, and on the first indication of such obstinacy three or four of the European officers immediately converged on the man and "rough-housed" him, stripping his clothes off him, hitting him, on occasion kicking him, and, if necessary, putting him on the ground. Blows struck were solid, hard ones, mostly with closed fists and about the head, stomach, sides and back. There was no attempt to strike at testicles or any other manifestations of sadistic brutality; the performance was a deliberate, calculated and robust assault, accompanied by constant and imperative demands that the man should do as he was told and change his clothes. ${ }^{167}$

163. Ibid.

164. A draft of this document is contained in the Hanslope files under the new catalogue reference: TNA FCO 141/6303.

165. TNA FCO 141/6303: details of the ministerial visit are omitted from the final draft sent to the Colonial Office, see TNA CO 822/1251.

166. TNA FCO 141/6303: "Dilution" Detention Camps. Use of Force in Enforcing Q20 Discipline."

167. Ibid., exactly the same text appears in the final document. 
Some "defiant" individuals attempted to raise the "Mau Mau moan," and, therefore, "it was essential to prevent the infection of this 'moan' spreading through the camp, and accordingly a resister who started it was promptly put on the ground, a foot placed on his throat and mud stuffed in his mouth. A man whose resistance could not be broken down was in the last resort knocked unconscious."168 Thereafter, the new intakes were forcibly shorn, and resisters were met with violence, similar to the violence at reception. In addition, when a detainee was asked if he intended to obey the camp regime "if he said 'no' or did not answer, he was immediately struck and, if necessary, compelled to obey by the use of force in the manner described above. Out of the total intake the part witnessed that day about a dozen needed minor 'persuasion' and 4 or 5 pretty rough treatment." 169

The concept of integrating the technique into the intake procedure was "to compel immediate submission to discipline and compliance with orders, and to do so by a psychological shock treatment which throws off balance and overcomes any disposition towards defiance or resistance."170 Shock treatment was justified because those " $Z$ " category detainees arriving from Manyani were "particularly ugly customers" according to the attorney- general, and were impervious to "orthodox methods of nonviolent persuasion."171 Indeed, he added, they were the type who understood violence, when there was no appreciable response to "gentler treatment."172 Serious injury was to be avoided, and to this end, the attorney-general explained how violence should be delivered in practice. ${ }^{173}$ Placing responsibility for Mwea procedure beatings in the hands of European officers was supposed to mitigate the consequences of dilution. Griffith-Jones was concerned about the impact that the administration of violence would have on the European officers involved, and urged the colonial secretary to support these officers "charged with this most difficult, dangerous and unenviable task." 174 To convey his point, the attorneygeneral referred to the Prison Rules of England, 1949, and read an implied

168. Ibid.

169. Ibid., exactly the same text appears in the final document.

170. Ibid.

171. Ibid.

172. Ibid.

173. "Serious injury must be avoided; kicking with boots or shoes should not be permitted; vulnerable parts of the body should not be struck, particularly the spleen, liver and kidneys; accordingly any blows should be confined to the upper part of the body and should avoid any area below the chest, front or back," Ibid.

174. Ibid. 
power to violence in rule 34(1) of the English code, to frame the following draft regulation

[d]iscipline and order shall be maintained with firmness. Force shall not be used in dealing with detained persons save when necessary to enforce discipline and preserve good order, and no more force than is necessary shall be used. Moreover, save by or under the personal direction of the officer-in-charge or, in the case of his absence or incapacity, the senior prison officer present in the camp, force shall not be used under this regulation except when immediately necessary to restrain or overpower a refractory detained person, or compel compliance with a lawful order or to prevent disorder. ${ }^{175}$

Thomas Askwith witnessed the moderated intake procedure on July 11, 1957, which was based on the attorney-general's draft regulation. A number of the procedures were "substantially the same;" however, there were some additional and troubling practices that violated the attorney- general's direction that injurious force should not be used, and Askwith "saw one man lifted up by an Officer to shoulder height and thrown down on the ground on his back three times." 176 Blows to the head were frequent, a practice that was explicitly prohibited in the attorney- general's directive: "one detainee at Mwea resolutely refused to respond in spite of a most drastic beat-up. He was thereupon dragged to the cells where Mr. Gavaghan informed me he would be subjected to third degree methods until he did, in fact, obey all orders given. The measures adopted were to be kept awake all night, having water thrown at him and to be beaten up on a variety of pretexts." 177 Against this, it is notable that Askwith's report, warning about the dangers of the Mwea procedure, was written only 6 days before Kariuki Muriithi died in his Gathigiriri cell after being subjected to water "shock treatment." 178 Askwith remained unconvinced of the technique's purported "successes," questioning whether a state of "cowed submission" could be long-lasting, and adding that "the methods employed are the negation of everything that rehabilitation has stood for so far." 179 Given the number of staff and detainees involved in the procedure, Askwith warned that it might become public knowledge,

175. TNA CO 822/1251: “Dilution" Detention Camps. Use of Force in Enforcing Discipline."

176. TNA FCO 141/6303: Rehabilitation - Mwea Camps, report by Thomas Askwith, Provincial Secretary for Community Development, July 12, 1957.

177. Ibid.

Q21 178. See s. on "Dilution" above.

179. TNA FCO 141/6303: Rehabilitation - Mwea Camps, report by Askwith, July 12, 1957. 
which would clearly be disagreeable to the British public. ${ }^{180}$ There is no evidence that Askwith's report ever reached the Colonial Office in Whitehall, as he was quickly and quietly marginalized by the Kenyan administration. ${ }^{181}$ Terry Gavaghan wrote a robust defense of his techniques, contested the substance of Askwith's report, and further accused Askwith of encouraging his "dirty work," insofar as Askwith allegedly made the following comment, "Don't think I am squeamish at all about this," during a camp visit. ${ }^{182}$

In the meantime, the colonial secretary was reluctant to approve Griffith-Jones's regulation, and the matter triggered great debate among colonial legal advisors in London. Shortly afterwards, Governor Baring discussed the matter with senior legal advisors at the Colonial Offices and signalled the possibility that he would accept an amended version of the Mwea procedure. First, detainees who refused a lawful order, such as the requirement to move from one compound to another, or to change their clothing, could be compelled to do so by means of "overpowering force," for which regulatory powers were already in existence. Second, committing a major offense, such as defying a lawful order, could attract on the spot corporal punishment (caning not exceeding twelve strokes). ${ }^{183}$ Extant summary punishment procedures for dealing with recalcitrant detainees could be invoked. ${ }^{184}$ When the colonial secretary questioned whether these powers would be sufficient in view of the critical task of maintaining the flow of detainees through the rehabilitation system, the governor responded that whereas the "treatment proposed would not administer the same psychological shock to the detainees," it was "adequate to be effective." 185 A telegram was duly dispatched to Kenya, and the Acting Governor, Richard Turnbull, circulated instructions for the modified procedure to the commissioner for prisons, the ministry for defence, the ministry for African affairs, and the attorney-general, specifying that the use of "beating force" was to be abandoned forthwith, and "overpowering force" used instead. ${ }^{186}$ Power to confirm corporal punishment

180. Ibid.

181. As a result of going against the tide, Askwith's colonial career abruptly ended and

Q22 his contract was terminated in December 1957; see From Mau Mau to Harambee: Memoirs and Memoranda of Colonial Kenya (Cambridge: Cambridge African Monographs, 1995).

182. TNA FCO 141/6303: "Report on Mwea Intake by Secretary for Community

Q3 Development," addressed to F.A. Loyd, Provincial Commissioner, Nyeri, July $22,1957$.

Q3 183. TNA CO 822/1251: note of a meeting by J.I.F. Buist, July 16, 1957.

184. The Emergency (Detained Persons) Regulations 1954, s. 17(a).

185. TNA CO 822/1251: Note by W.A.C. Mathieson, July 18, 1957.

186. TNA FCO 141/6303: Mwea Procedure by Acting Governor, R.G. Turnbull, July 17, 1957. 
was additionally delegated to the assistant commissioner and the deputy commissioner of prisons, one of whom had to be present at each new intake. In this manner, the sentence of corporal punishment could be confirmed on the spot. ${ }^{187}$ In a sense, modifying the regulatory framework of detainee "corporeal violence" was an experiment with disciplinary techniques and technologies of governance that aimed to maintain colonial power in the camps.

The modified Mwea procedure had the unintended consequence of slowing down the passage of detainees through the pipeline, because the officer in charge had to formally confirm and oversee the execution of corporal punishment on individual detainees. To expedite the process, noncooperating detainees were physically separated from cooperating detainees and punished en masse. ${ }^{188}$ The governor met with Gavaghan, John Cowan (the senior prison officer in charge of the Mwea camps), and several government ministers at Government House on August 6, 1957 to tease out the finer details of the modified procedure. ${ }^{189}$ The governor highlighted the following points, "the force to be used should be overpowering force only," and that "in order to defend the position it was very important that over a period of, say three months, the percentage beaten following orderly room proceedings should not exceed about $10 \%$," and, finally, that "we should keep up-to-date each month a dossier showing the results obtained with all detainees taken into the Mwea and particularly with those who at the time of intake had been beaten." ${ }^{190}$ Cowan affirmed the implementation of the procedure, describing the intake of detainees at Mwea camp "[t]he first batch of 20 arrived at Mwea camp at approximately $12.15 \mathrm{pm}$ and immediately offered strong resistance to being shaved and clothed. Considerable overpowering force was necessary in probably 15 cases out of 20 and the final instruction to proceed to the compound was only accepted after frequent and aggressive repetition."191 "Rough methods" were similarly required in dealing with three subsequent batches, but only two men received the official punishment. ${ }^{192}$ There was a gradual

\section{Ibid.}

188. TNA FCO 141/6303: letter to Jack Cusack from Gavaghan, July 27, 1957.

189. TNA FCO 141/6303: meeting at Government House, August 8, 1957. In attendance at this meeting were Governor Baring, John Cowan, Terry Gavaghan, and government ministers.

190. Ibid.

191. TNA FCO 141/6303: letter to the commissioner of prisons from Cowan, dated August 10, 1957.

192. Ibid., in a subsequent report from Cowan, the Commissioner of Prisons, "No resistance was encountered from the Gathigiriri intake with the exception of the first man into the compound who instantly fought like a fanatic. This man was dangerous, striking both officers and warders, and had to be severely restrained apart from receiving twelve strokes." The man who received the beating remained "uncompromising," August 16, 1957. 
disjunction among some of the safeguards that were supposed to be applied to the modified technique, and the actual implementation in practice. A

Q3 Special Branch Officer, I.P. Kelloway, noted that detainees who wished to make a confession were immediately screened, whereas " $[t]$ he remainder are asked individually if they have taken an oath. If they deny having taken an oath they are given summary punishment which usually consists of a good beating up. This treatment usually breaks a large proportion. If this treatment does not bear fruit the detainee is taken to the far end of the camp where buckets of stones are waiting. These buckets are placed on the detainee's head and he is made to run around in circles until he agrees to confess the oath." ${ }^{193}$ Kelloway observed that approximately $80 \%$ of the new detainees confessed on the day of their arrival, whereas others took a day or thereabouts to comply. He further remarked that "at Thiba Works Camp the treatment usually consists of beating the man with the regulation baton which to date and to my knowledge, has resulted in one person being placed in hospital with broken arms and a leg, and another person suffering a perforated ear-drum. At Gathigiriri one person received injuries but to what extent I have been unable to ascertain as I was not present. Any other injuries that may have been caused have not been brought to my notice." ${ }^{194}$ When the provincial commissioner learned of Kelloway's report, he advised against investigating the matter, because "an investigation would have a strong adverse effect on the morale of officers at the Mwea Camps, who, in any event had a most difficult and distasteful job to perform and that the report was untrue or at best greatly exaggerated in certain essentials." 195 In the end, "overwhelming force" was in practice no different from "beating force," the only difference was semantic; on September 12, 1958, a detainee arriving at Agathi camp from Nyeri Prison died after undergoing the modified Mwea procedure. A postmortem revealed significant external injuries, and the cause of death was recorded as a pulmonary embolism. ${ }^{196}$

\section{Forced Labor and the Cowan Plan}

The United Kingdom was instrumental in garnering support for the 1930 Q8 ILO Forced Labour Convention, which had the effect of immediately

193. TNA FCO 141/6303: I.P. Kelloway, Officer in Charge of Detainee Section, Special Branch, Embu, writing to the senior assistant commissioner of police, November 28, 1957. 194. Ibid.

Q3 195. TNA FCO 141/6303: Trent to the commissioners of police, Catling, December 19, 1957.

196. TNA FCO 141/6305: letter to the permanent secretary for home affairs from the provincial commissioner, Central Province, September 17' 1958. 
prohibiting all forms of forced labor for private purposes. ${ }^{197}$ The primary task of the 1930 Forced Labour Convention was to eliminate the conditions under which individuals were coerced into slavery or slave-like situations. ${ }^{198}$ Daniel Maul notes that there were loopholes in the Convention, such as with military service, penal servitude following criminal conviction, and service that could be considered as part of the "normal civic obligations of citizens." 199 The following exemption to the prohibition on forced labor found in Article 2(2)(d) of the 1930 Convention was relied on by the British government in rationalizing its forced labor policy: "any work or service exacted in cases of emergency, that is to say, in the event of war or of a calamity or threatened calamity, such as fire, flood, famine, earthquake, violent epidemic or epizootic diseases, invasion by animal, insect or vegetable pests, and in general any circumstance that would endanger the existence or the well-being of the whole or part of the population." 200 The limited impact of ILO norms on the colonies has been critiqued by Maul who suggested that separate and less stringent rules applied to the colonies before the Second World War, and further, that "neither the internal power structures of the ILO nor the thinking of its officials permitted the application of the regular canon of norms to the colonies."201 Following the war, the self-determination ambitions of colonial states were, in principle, supported by the United States, and, therefore, postwar exploitation of the colonies had to be carefully justified by the United Kingdom. ${ }^{202}$ During a governor's emergency meeting on April 16,1953, a finance official highlighted the twin effect of making detainees work "from the point of view of morale, as well as finance." ${ }^{203}$ The Colonial Secretary, Oliver Lyttelton, quickly authorized a regulation that permitted the extraction of labor from detainee suspects held in camps across the colony, powers that were contained in the Emergency (Detained Persons) Regulations $1953 .{ }^{204}$ The ordinance was subsequently modified in an effort

197. Maul, Human Rights, Development and Decolonization, 24, 25. For more background on the United Kingdom's engagement in this process, see TNA CO 323/1027: "Proposed International Convention on forced labour."

198. Cooper, Decolonization and African Society, 29.

199. Maul, Human Rights, Development and Decolonization, 27.

200. C029 - Forced Labour Convention, 1930 (No. 29), Convention concerning Forced or Q23 Compulsory Labour, (Entry into force: May 1, 1932) Adoption: Geneva, 14th ILC session (June 28, 1930), article 2(2)(d).

201. Maul, Human Rights, Development and Decolonization, 27.

202. Cooper, Decolonization and African Society, 112.

203. TNA FCO 141/5666: Governor's Emergency Meeting, Memo for the Member of Legal Affairs, April 16, 1953.

Q3 204. TNA FCO 141/5666: memorandum on the forced labor regulation by R.I. Guthrie, Assistant Legal Drafstman, April 30, 1953. 
to comply with international law, but on the whole, these efforts were cosmetic, and completely disregarded the illegal violence that was used to compel detainees to work. Forced labor became a flashpoint of violence between uncooperative detainees refusing to work and the camp authorities who used "compelling force" to enact the policy. The implementation of the scheme resulted in detainee deaths, most notably the notorious 1959 Hola Massacre, during which 11 detainees were killed. A closer examination of the "migrated archives" reveals several other violent incidents associated with forced labor prior to the events of March 3, 1959.

Serious allegations were promulgated in a detainee petition from Manyani Special Detention Camp, which was addressed to the secretary of state for the colonies, calling on the government to investigate " $[\mathrm{t}] \mathrm{he}$ many deaths which occurred among the detainees who catered for the digging of the Embakasi Air Field. It is a fact that while the detainees performed the task they suffered malicious and brutish beatings by the warders, and this brought about an average of three "on the spot" deaths Q3 per day, during 1953-1954." ${ }^{205}$ H.F.H. Durant, the officer in charge of Manyani Special Detention Camp, categorically denied the allegations of brutality, which, in his estimation, were a "collection of wild and misleading generalities without support by any concrete evidence" and "gross and unjustified allegations" against European officers. ${ }^{206}$ As it turns out, a 1955 memo by the Ministry of Defence on the "Movement of Detainees from Reception Centres to Works Camps" unequivocally states that certain development projects were "planned on the assumption that free convict labour [would] be available," and that the Embakasi airport development was one such project, ${ }^{207}$ "[i]n order to keep up the labour force on certain essential projects such as Embakasi airport, it will be necessary in the next few months to transfer convicts from a number of the more remote prisons and prison camps." 208 That was to say, ex-convicts, having served their sentences, were issued detention orders and forced to work on these

Q3 205. TNA FCO 141/5667: petition sent from J.G. Kariuki and S.M. Macharia from Manyani Special Detention Camp to the secretary of state for the colonies, April 1956.

206. TNA FCO 141/5667: H.F.H. Durant to the commissioner of prisons, May 12, 1956.

Q3 207. An allegation submitted by Captain Law, a former officer in the prisons systems, refers to "alleged beatings of Embakasi convicts in March 1958 and implies that convicts were merely refusing to come out and were not violent and that excessive forces was used by Turner, Haig-Thomas, Carnie, Bird and Morton. There was no resistance and prisoners could not defend themselves - 'it was just a murderous onslaught'." It is not clear whether Law was referring to detainees working on the Embakasi project, see TNA FCO 141/6307: telegram from the colonial secretary to the governor, September 29, 1959.

208. TNA FCO 141/6520: Movement of Detainees from Reception Centres to Works Camps, Council of Ministers on the Resettlement Committee. Memorandum by the Ministry of Defence, May 5, 1955. 
projects for nominal remuneration, "paid from Emergency funds." ${ }^{209}$ It was estimated that approximately half of the 6,500 Kikuyu prisoners due to be released in 1955 would be served detention orders, and immediately reassigned to these "essential projects." 210 A letter composed by Mageta Island detainees in November 1956 remarked that "50 detainees were charged of refusing accepting [sic] work at the pay of 8/- per month and were sentenced to 2 years hard labour," and although the commissioner of prisons contested other allegations contained therein, this specific accusation was ignored. ${ }^{211}$

There may have been some truth to the charge that detainees who refused to work at Mageta Island were criminalized for disobedience, and, therefore, received additional penal servitude. There was one such reported incident at the camp in June 1956, when detainees refused to work at bush clearing. ${ }^{212} \mathrm{Up}$ until that point, refusing to work was deemed a minor offense, a violation that could only be punished by a verbal reprimand, reduced diet, denial of privileges, or solitary confinement for up to 7 days. The Kenyan administration sought to redefine disobedience as a major offense, punishable by corporal punishment. ${ }^{213}$ Repeat offences, under Section 23 of the Regulations, could result in "prosecution before a subordinate court and on conviction [...] imprisonment for a term not exceeding Q3 two years." 214 W.A.C. Mathieson, a senior legal advisor with the Colonial Office, realized that "in effect, therefore, the Governor is asking for authority to employ corporal punishment to break this strike." 215 He sought counQ3 sel from Colonel Heaton, a member of the Colonial Office's Advisory Committee on the Treatment of Offenders and a former commissioner of prisons in Kenya, who, although doubtful as to whether the punishment would expedite the forced labor scheme, considered that "discipline must be reasserted and that it would be wrong to withhold the use of this weapon from those in Kenya who have the responsibility for enforcing discipline." 116 Mathieson accepted this view, and advocated for the "authority

209. It is unclear from the Ministry of Defence memo whether these individuals had been convicted of ordinary crimes or terrorist-related offenses, see ibid.

210. Ibid.

211. TNA FCO 141/5671: A letter on behalf of 2,000 detainees at Mageta Island, November 20, 1956.

212. TNA FCO 141/6322: War Council, the Emergency (Detained Persons) Regulations, 1954 , memorandum by the minister for defence.

213. The new regulation covered: "Disobedience in such manner as to show wilful defiance of authority, of any order lawfully given," in ibid.

214. Ibid.

215. TNA CO 822/802: Memo by W.A.C. Mathieson, August 27, 1956.

216. Ibid. 
to use this weapon." 217 The next day, the colonial secretary sent Governor Baring a telegram authorizing the creation of the additional major offense; ${ }^{218}$ the amending regulation was published on September 4, and on September 10, strikers at Mageta Island were informed of the new powers. ${ }^{219}$ Disciplinary action was taken against the detainees who persistently refused to work, and a telegram from Baring to the colonial secretary indicates that fifty Mageta Island detainees who refused to work were to be prosecuted under Regulation 23, corroborating the detainees' complaint mentioned previously. ${ }^{220}$

The matter did not end there. The Mageta Island petition alluded to a violent incident during which detainees were beaten, "shorts [sic] were fired in one of the camps holding 800 men, and 13 people were wounded." 221 By contrast, the official version recounted a story of violent detainees armed with "stones and other materials" attacking a prison party, and in this narrative, Greener guns were only discharged so that the party could withdraw. 222 The "belligerent" detainees were deprived of water and food for a number of days, after which point a military squad went into the compound to "disarm" them "[t]his was done and in the course of the operation some 30 to 40 detainees suffered from minor superficial injuries, of whom some 22 had their cuts subsequently stitched by the Medical Officer. At the same time 15 ringleaders were extracted from the compounds and placed in the small cells where disciplinary action under Section 17 of the Emergency (Detained Persons) Regulations, 1954 is to be undertaken."223 The commissioner of prisons sanctioned the use of corporal punishment, not only for the "ringleaders," but also for the remaining 860 detainees. $^{224}$

A letter written by Mbirua Githua smuggled out of Aguthi camp to a British MP alleged that eighty-seven detainees had been badly beaten upon reception to the camp on October $24,1958 .{ }^{225}$ A former officer in

217. Ibid.

218. TNA CO 822/802: telegram from the colonial secretary to the governor of Kenya, August 28, 1956.

219. TNA CO 822/802: telegram from Governor Baring to the colonial secretary, September 19, 1956.

220. TNA CO 822/802: telegram from Governor Baring to the colonial secretary, October $3,1956$.

221. TNA FCO 141/5671: a letter on behalf of 2,000 detainees at Mageta Island, November 20,1956. (The date on the letter precedes an event described therein.)

222. TNA FCO 141/6322: Disturbances at Mageta Island, report written by J.H. Lewis, Commissioner of Prisons, November 28, Commissioner of Prisons.

223. Ibid.

224. Ibid.

Q3 225. TNA FCO 141/5662: This letter is mentioned in a memorandum by D.W. Conroy, Attorney-General, May 27, 1959. 
charge of the camp wrote a most forthright account of the intake when "some Kikuyu detainees started to boo and taunt those who had submitted confessions to the Screening teams," and he realized that "something had to be done..."226 and that "they had obviously to be brought under control, and as they would not listen to commands from me or the camp staff I called in the Special Platoon to deal with them. These warders used batons on the more aggressive detainees, and inevitably some were badly bruised. The doctor considered that a few men, (I think, four), should be treated at the camp dispensary." 227 Men who refused to work the following day "received" lights blows with batons, whereas on the 3rd day the "recalcitrants" were put on half rations. The strike lasted until November 22, 1958, when thirteen "non-cooperating detainees" were sent to Karaba camp. Nine of these detainees "confessed" and were returned to Aguthi, where they subsequently retracted their confessions. Permission was granted to cane these nine men; eight of whom were caned on December 16. The officer in charge of the camp admitted certain irregularities as regards the punishment:

I must also testify to the fact that in some cases more than the stipulated numbers of strokes were given. Moreover, previous experience had taught me that punishment with the regulation prisons case had no effect other than to make the detainees mock at the authorities and deliberately try to incur more punishment to show how little they cared. I mentioned this to my superior officers on occasions before this incident occurred and suggested that, if corporal punishment was approved, it was presumably intended to make some real impression and therefore something other than the kind of cane which was used to punish me at school should be employed, namely a "kiboko." I gathered the impression that everyone agreed with me and that is why a "kiboko" was used and not the regulation cane ordered in the signal from the SSP. A member of the staff entered the punishment as twelve strokes in the register before the beating. When I went to sign the register after the beating it was agreed not to alter the entry. ${ }^{228}$

The attorney-general instituted a Criminal Investigation Department (CID) probe into the caning because there had been no inquiry prior to sentencing, a regulation cane was not used, and excessive strokes had been delivered. ${ }^{229}$ However, instead of criminal charges being made against the officer who authorized the use of the "kiboko," "severe disciplinary action"

Q3 226. TNA FCO 141/5662: letter from Brooks to the minister of home affairs, May 13, 1959.

227. Ibid.

228. Ibid.

Q3 229. TNA FCO 141/5662: memorandum by D.W. Conway to the Ministry for African Affairs and the Ministry of Defence, May 27, 1959. 
Q3 was instituted by C.M. Johnson, the Minister for African Affairs. ${ }^{230}$ In a sense, defining the action as a "disciplinary violation" sabotaged the CID inquiry, and the criminal investigation was subsequently abandoned. ${ }^{231}$

The violence of the state in enforcing the forced labor policy was laid bare when detainees persistently refused to work at Hola detention camp. In a meeting at Government House, the permanent secretary of the ministry for African affairs stated that Hola received "the dregs of the Mau Mau barrel."232 In receiving these "violent men from Manyani" and "persons unacceptable in the Central Province," the permanent secre-

Q3 tary reminded D.A. Marsden, the district officer in charge of the settlement camps at Hola, that "certain persons are always ready to listen to complaints from detainees, even though the statements made are false and exaggerated. It is essential that there should be no grounds for any legitimate complaint. Prisons rules and detention camp regulations must be followed precisely."233 However, in August 1958, a number of detainees were "beaten because they refused duty," resulting in the hospitalization of four detainees. ${ }^{234}$ This incident would have been assigned to the annals of historical amnesia, were it not for the killings at the camp later in March 1959.

From the declassified archives, it appears that there were two key factors that led to the creation of the Cowan plan, the forced labor policy implemented at Hola on March 3, 1959. First, the Commissioner of Prisons, John H. Lewis, noted with frustration on February 5, 1959, that there were a number of "apparently able-bodied men" "malingering" about Hola, refusing to work outside the camp. ${ }^{235}$ A second source of frustration for camp officials was that even the detainees who were working ("out on shamba") were adopting a "go slow" policy and were not achieving their designated labor targets. ${ }^{236}$ The Cowan plan would tackle both of these problems; summary punishment, that is on the spot corporal punishment,

\section{Ibid.}

231. TNA FCO 141/5662: letter from C.M. Johnston to the minister for legal affairs, June 3, 1959.

232. TNA FCO 141/5653: Ministry of Defence minute of a meeting held at Government House, December 1, 1958.

233. TNA FCO 141/5653: directive from permanent secretary to the District Officer $\mathrm{i} / \mathrm{c}$ Settlement Camps, Hola, D.A. Marsden.

234. TNA FCO 141/5662: The medical register at the hospital recorded that Mutai Theuri, Mbuthia Thairu, Ndeqwa Gacheo, and Mwema Kinuthia were: "Beaten by squad for refusing duty." This incident occurred toward the end of August 1958.

235. TNA FCO 141/5658: "Discipline - Hola Closed Camp," letter from J.H. Lewis, Commissioner of Prisons to Officer in Charge at Hola, February 5, 1959.

236. TNA FCO 141/5658: situation report from Hola camp to the commissioner of prisons, February 13, 1959. 
was the preferred solution for dealing with the "go-slow" policy, but ensuring "absolute obedience from the 66 recalcitrant" detainees refusing to work required a more sophisticated strategy. ${ }^{237}$ On the selected day "difficult cases" were to be divided into four smaller groups, and each group was to be locked into an A-frame building. A special platoon was to target the first group, enter their compound, and usher them into the catwalk, at which point the officer-in-charge would order the detainees to work on a labor scheme "requiring no tools or implements... it is assumed that the party would obey this order but should they refuse they would be manhandled to the site of work and forced to carry out the task." ${ }^{238}$ Each group in turn would be removed "until all were working," 239 and Cowan insisted that "obedience must be maintained by more firmness on the part of the staff," but that this did not "imply a brutal and harsh regime but a high standard of personal example and insistence always on immediate obedience." 240 Not everyone supported Cowan's plan, and less than a week later, the commissioner of prisons wrote to the Kenyan minister of defence, warning that the plan "would mean the use of a certain degree of force in which operation someone might get hurt, or even killed."241

\section{The Hola Massacre}

Despite the warnings, on March 3, 1959, a group of "hard-core" detainees who persistently refused to work were savagely beaten by warders implementing the Cowan plan at Hola detention camp. Eleven detainees were killed, and dozens more were hospitalized with severe injuries. ${ }^{242}$ A coroner's inquest revealed some of the injuries sustained, such as, "one received a fractured skull... another's brains were damaged, one had a fractured jaw and two had fractured forearms." ${ }^{243}$ The first official account Q3 to emerge can be seen as a complete whitewash. W.M. Campbell, Assistant Commissioner of the Prison Service, reported that it was "the opinion of all with whom we spoke that the compelling exercise was in no way

237. TNA FCO 141/5658: notably, the work scheme manager, Mr. Filgate, "asked to be dissociated entirely" from Cowan's plan; situation report from Hola camp to the commissioner of prisons, February 13, 1959.

238. TNA FCO 141/5658: "The Cowan Plan," February 11, 1959.

239. Ibid.

240. Ibid.

241. TNA FCO 141/5658: note from Lewis, Commissioner of Prisons, to the minister of defence, February 17, 1959.

242. Elkins, Imperial Reckoning, 347.

Q24 243. TNA CAB 129/97 C92: memorandum from the colonial secretary to the Cabinet, June 2, 1959, para. 13. 
244. TNA CAB 128/33/CC32: Cabinet minutes, June 20, 1959.

Q3 The only resulting "sanction" was that the Camp Commandant, G.M. Sullivan, was forced to retire without any loss of gratuity, and the Commissioner of Prisoners, John Lewis, was forced to retire 6 months early, whereas Walter Coutts, Sullivan's deputy, was absolved of any

Hola," March 4, 1959.

246. TNA CAB 129/97 C92: memorandum from the colonial secretary to the Cabinet, June 2, 1959, para. 15.

247. Ibid., para. 14.

248. "Section 18 of the Prisons Ordinance authorises the use of weapons, where necessary, by prison officers against detainees escaping or attempting to escape, engaged in a combined outbreak or using violence to any prison officer or other person. Prison Standing Orders forbid the striking by prison officers of persons in custody save to the extent necessary in defence or to overcome violence or resistance to escort. The Emergency (Detained Persons) Regulations, 1954, prescribe the circumstances and manner in which corporal punishment may be applied to detainees for offences against discipline," Secret memorandum detailing the attorney-general's reasons for deciding not to prosecute, TNA CAB 129/97 C92, annex I, para. 9.

249. Secret memorandum detailing the attorney-general's reasons for deciding not to prosecute, TNA CAB 129/97 C92, annex I.

250. TNA CAB 128/33/CC32. 
wrongdoing in the matter. ${ }^{251}$ Several British MPs argued that responsibility for the events lay with those ranked above Sullivan and Coutts, with the government of Kenya, with Governor Baring, and, ultimately, with the secretary of state for the colonies. The failure of the inquiry to "pin down responsibility all along the chain of command" was criticized by Ronald Robinson, MP, who believed that it was a breach of ministerial responsibility to permit junior officers to shoulder the blame for this atrocity. ${ }^{252}$ Criminal charges were not pursued, he argued, because "quite instinctively, sincerely and genuinely, without even being aware of it, hon. Members opposite do not believe that an African life is as important as a white man's life." 253 This sentiment was echoed by the Conservative MP Enoch Powell, who departed from the Tory party line, and criticized the idea of African standards for Africa or lower standards of justice than those applicable in Britain. Powell argued that it was inappropriate to "pick and choose where and in what parts of the world we shall use this or that kind of standard... We must be consistent with ourselves everywhere. All Government, all influence of man upon man, rests upon opinion. What we can do in Africa, where we still govern and where we no longer govern, depends upon the opinion which is entertained of the way in which this country acts and the way in which Englishmen act. We cannot, we dare not, in Africa of all places, fall below our own highest standards in the acceptance of responsibility." 254 Finally, Barbara Castle, a great advocate of detainees' rights in Kenya, recognized that to accept the government's recommendations would result in "one of the gravest miscarriages of justice in British colonial history." 255 In the end, the opposition made a tactical error when it failed to submit a motion on the question of holding an independent inquiry into the massacre, and, therefore, no vote was taken after the debate, which allowed the government to evade accountability. ${ }^{256}$ Although an internal review (the Fairn Commission) was established to investigate the procedures along the pipeline, similar to the Glenday Inquiry, it had no mandate to investigate past incidents, but could only make prospective recommendations. ${ }^{257}$

251. Walter Coutts was a district commissioner and deputy to Sullivan, the Camp Commandant. Hansard, House of Commons, vol. 610, col. 181, July 27, 1959.

252. Ibid., col. 216.

253. Ibid., col. 220.

254. Ibid., col. 237.

255. Ibid., col. 222.

256. Elkins, Imperial Reckoning, 353.

257. Ibid., 349. See also, Klose, Human Rights in the Shadow of Colonial Violence, 182. 


\section{Accountability for Abuses}

Recently, in the Mutua and Others case, the FCO claimed that security force indiscipline and allegations of ill-treatment during the emergency had already been investigated. ${ }^{258}$ There were no outstanding issues with respect to state-sponsored violence in British Kenya, so the government argued, when providing the court with a list of historic prosecutions. In March 1954, Colonel Arthur Young, on secondment from the city of London, was instated as police commissioner of Kenya to tackle the culture of impunity. Young, together with Donald MacPherson, head of the CID, attempted to prise open a space for CID inquiries into abuses committed by the police, the army, and the Kenyan Home Guard. ${ }^{259}$ The first of these cases, the Wamai case, which Young and MacPherson prosecuted, is worth examining in more detail because it points to executive interference in what should have been a matter for the judiciary.

\section{Contemporary Accountability}

The case against Muriu Wamai, a Home Guard headman, and his five codefendants, stemmed from the deaths of two Kikuyu farmers who were beaten and tortured at the Ruthagathi Home Post. The two Kikuyu refused to confess Mau Mau allegiance and were taken outside the town and executed. ${ }^{260}$ Initially, Wamai claimed that their deaths occurred as a result of a shootout between Home Guards and Mau Mau insurgents, although evidence given by former detainees indicated that detainees were routinely beaten at the Home Guard post. The European officers compelled to give evidence supported Wamai's account of events. ${ }^{261}$ However, on the 3 rd day in the witness stand, Wamai dramatically changed his plea and gave a full confession. ${ }^{262}$ The British officers were well aware that the Home Guard post was a "screening center" where torture was institutionalized, and Wamai had been encouraged to cover up the incident by a British District Officer. ${ }^{263}$ Alterations to the Home Guard post logbook concerning the prisoners were made after the killings. Wamai's confession

258. Ndiku Mutua and Others $v$ The Foreign and Commonwealth Office [2011], witness statement of David Anderson.

259. Anderson, Histories of the Hanged, 298-99; Elkins, Imperial Reckoning, 276.

260. Anderson, Histories of the Hanged, 298.

261. Ibid., 301.

262. Ibid., 302.

263. Ndiku Mutua and Others $v$ The Foreign and Commonwealth Office [2011], appendix C, para. (i). 
implicated five British officers and an African chief in the subsequent conspiracy. ${ }^{264}$

Issuing his judgement on December 4, 1954, Justice Cram found Wamai and his codefendants guilty of murder and the judge, a former prisoner of war, was vitriolic about the conduct of European officers in the South Nyeri district. ${ }^{265}$ Unchecked arbitrary powers contributed to a barbaric detention and interrogation system that Justice Cram declared was illegal. ${ }^{266}$ Contrary to the officials' claim that the allegations of murder were part of a Mau Mau plot to discredit loyalist Home Guards, Cram found "the only plots revealed by their evidence [the European officers] is a plot to execute innocent prisoners, and then a plot to defeat the ends of justice, and maintain the barbarous tortures of Ruthagathi... They were a prey [sic] on the countryside. .."267 Justice Cram recognized that it was a short step from brutalized beatings and torture to "taking life without qualm."268 Governor Baring attempted to suppress publication of the judgment; however, copies were leaked, causing quite a stir in the United Kingdom. ${ }^{269}$ An inquiry resulted, presided over by a conservative judge, Justice Holmes, who concluded that Justice Cram had "grossly exaggerated the problems." ${ }^{270}$ Many were dissatisfied with the Holmes report, including the president of the East African Court of Appeal, who wrote to Governor Baring to request that the first section of the report, which gave the impression that outstanding issues from the Wamai case had been settled, be withheld. ${ }^{271}$ The governor agreed to this proposal, which, according to Anderson, was a "tacit admission that the matters raised by Justice Cram in his judgment in the Ruthagathi case had not in fact been properly investigated by the Kenya administration, despite the establishment of a full judicial inquiry." 272

At every level, the CID experienced obstruction in their attempts to further criminal prosecutions against colonial staff. ${ }^{273}$ The colonial government's

264. Two European officers committed perjury and one gave a false statement to the court, Anderson, Histories of the Hanged, 303.

265. Criminal Case No. 240 of 1954 of HM Supreme Court of Kenya at Nyeri.

266. Ibid., 8.

267. Ibid.

268. Ibid.

269. Ndiku Mutua and Others $v$ The Foreign and Commonwealth Office [2011], appendix C, para (i).

270. Anderson, "Histories of the Hanged," 306.

271. Ndiku Mutua and Others v The Foreign and Commonwealth Office [2011], witness statement of David Anderson, s. 16.

272. Ibid.

273. Ndiku Mutua and Others $v$ The Foreign and Commonwealth Office [2011], appendix C, para (j). 
approach was to maintain the detention pipeline and security force morale, even at the expense of justice in individual cases. ${ }^{274}$ Colonel Young sent Governor Baring a series of communications between November and December 1954, highlighting the difficulties he was encountering, but this correspondence was unacknowledged, and in his frustration he resigned his post pointing to "the continuance of the rule of fear rather than that of impartial justice." 275 At the center of his predicament were "malpractices committed against Mau Mau suspects" that were "condoned by officers of the Provincial Administration," and in his resignation letter, which he submitted to Governor Baring, Young stated that the governor himself had attempted to interfere in the prosecution of one of these cases. ${ }^{276}$ Young's letter was not made public and he was forced to tone down the language contained therein. Later, Young recalled how he had sent "an official report to HE [His Excellency] expressing my apprehensions in writing, with the belief that supporting evidence would soon be forthcoming. I also requested that he should take an initiative in administration of action which would indicate his own repugnance of brutality committed by security forces and do what he could to bring this to an end. I received no acknowledgement of this appreciation, far less an answer to it, in spite of a number of reminders." 277 On January 18, 1955, the government announced a general amnesty for all violent actions committed by both the security forces and "Mau Mau surrenderers" up until that point. ${ }^{278}$ On paper, the amnesty was accessible to insurgents, however, to avail themselves of it, the rebels had to emerge from hiding and surrender their arms. Overall, it had the effect of preventing CID investigations into security force malpractices from coming to trial. ${ }^{279}$ The amnesty perpetuated the lack of security force accountability, and, according to Elkins, "the blanket pardon left little doubt that the colonial government, including Churchill and his cabinet, who discussed and approved the amnesty, were wholly willing to abandon the enforcement of law and order and to subordinate the basic human rights of Mau Mau adherents in order to maintain the support of the security forces and, ultimately, uphold British colonial rule in Kenya." 280 Today, blanket amnesties are inimicable

274. Anderson, Histories of the Hanged, 300.

275. Ndiku Mutua and Others $v$ The Foreign and Commonwealth Office [2011], appendix C, para (j).

276. This case was the attempted prosecution of Home Guard Chief Mundia, Klose, Human Rights in the Shadow of Colonial Violence, 179-80.

277. RH, Mss. Afr. s. 486, Sir Arthur Young, papers, box 5, file 1, Arthur Young, "Introduction to Sir Arthur Young," n.d., 14.

278. Bennett, Fighting the Mau Mau, 27.

279. Anderson, Histories of the Hanged, 308.

280. Elkins, Imperial Reckoning, 280. 
to international law principles, such as the duty to prosecute and punish gross human rights violations and the fulfilment of a right to a remedy. ${ }^{281}$ However, at that time, acts of indemnity had historical precedent in England, with the English jurist, Alfred Venn Dicey admitting that although "it is the legalisation of illegally," the statute is essentially law, and could only be questioned if indemnification pertained to, for example, "reckless cruelty to a political prisoner," or "the execution of a political prisoner."282 That said, there is a deep ambivalence in Dicey's legal scholarship, whereby his principles of nondiscrimination and equality before the law were largely abandoned in his wholehearted support of Irish coercion laws. ${ }^{283}$ Therefore, his exceptions to indemnification probably would not have stretched to colonial violence and counterinsurgency.

Up until that point, there were several judgements at the East African Court of Appeal that queried whether the unlawful violence of detention could have continued "without the condonation [sic] of the authority." 284 Corruption was pervasive, and the appeals court protested against "the ill treatment of captives." 285 Judicial recommendations for security force prosecution were ignored, and the lack of consequences for criminal violence resulted in the police force of Kenya becoming "a law unto itself."286 Convictions were few and far between, and punishment was often perfunctory. ${ }^{287} \mathrm{~A}$ memorandum prepared by the colonial secretary defending the administration's response to security force violence referred to six cases, none of which resulted in a custodial sentence for the European officers involved. 288

281. Louise Mallinder, "Can Amnesties and International Justice Be Reconciled?" The International Journal of Transitional Justice 1 (2007): 210, 213. Mallinder recommends prosecuting the most guilty perpetrators of the worst atrocities, whereas conditional amnesties for lower level offenders may be commensurate with international law, treaty, and custom.

282. Alfred Venn Dicey, Introduction to the Study of the Law of the Constitution (Liberty Fund: Indianapolis, 1982), 145.

283. Alfred Venn Dicey, England's Case Against Home Rule, 3rd ed. (London: John Murray, 1887).

284. Criminal Appeals 988 and 989 of 1954 (from Emergency Assize Criminal Case No. 584 of 1954 of HM Supreme Court of Kenya at Nairobi), KNA: MLA 1/1098. See witness statement of David Anderson for a list of relevant cases.

285. Criminal Appeal No.818 of 1954 of Criminal Case No.289 of 1954 (Nyeri).

286. Criminal Appeals 549, 550, 551, and 552 of 1954 (from Emergency Assize Criminal Case No. 330 of 1954 of HM Supreme Court of Kenya at Nairobi) KNA: MLA 1/905.

287. Anderson, Histories of the Hanged, 310, 311; Elkins, Imperial Reckoning, 278, $282-84$.

Q3 288. A commandant of Mara River detention camp, L.W. Lemon, was charged of causing actual bodily harm, but he was convicted of the lesser offence, common assault, and fined sh.500. Jasiel Njau, an African rehabilitation officer in the Gathigiriri Works Camp, was acquitted of murdering a detainee in January 1957, but convicted and sentenced to 12 months 
The foregoing discussion raises the question of whether the detention regime instituted by the British government in the colony of Kenya was permissible under international law. Article 3 of the Universal Declaration of Human Rights (1948) holds that "Everyone has the right to life, liberty and security of person," whereas Article 5 provides that "No one shall be subjected to torture or to cruel, inhuman or degrading treatment or punishment."289 Although the Declaration was not a legally binding instrument, ${ }^{290}$ there was unanimity among the diverse member states involved in legislating "on behalf of all peoples and all nations" regarding the importance of human rights norms after the war. ${ }^{291}$ Colonized peoples were not represented in these negotiations, although Third World activists, according to Roland Burke, played a more significant role in contributing to the new human rights discourse after decolonization. ${ }^{292}$ Although there was an assumption that the Declaration would apply to all colonies and dependencies, ${ }^{293}$ "screening," "dilution," and the "Mwea procedure" as practised in detention facilities across Kenya were contrary to the spirit of the Declaration. ${ }^{294}$ The emergency in Kenya began shortly after crimes against humanity were first prosecuted by the International Military Tribunal at Nuremberg, and international humanitarian law was already an established body of law. ${ }^{295}$ Mau Mau insurgents would not have met the strict criteria for "irregular forces" set out by customary humanitarian law, which would

imprisonment for manslaughter. The attorney-general decided not to prosecute the senior European officers associated with this case, although they were subject to disciplinary charges. In October 1957, Mr C.R. Harrison and two of the European officers were acquitted of the charge of causing actual bodily harm, when using force to extract labor from detainees. And finally, another case of the unlawful killing of a detainee during interrogation in the Gathigiriri camp resulted in the acquittal of two African interrogators on murder charges, with the imposition of a 3 year sentence for manslaughter, whereas the camp supervisor,

Q3 Mr D.D. Luies, who was absent from the camp at the time of the incident, only received a reprimand. TNA CAB 129/97 C92.

289. There are several other interlocking articles (including articles 2, 7, 8, 9, 10, 11, 12, 13, 19, and 20) that were contravened in Kenya during the emergency.

290. It may now have standing as part of customary international law.

291. Burke, Decolonization and the Evolution of Human Rights, 1.

292. Ibid.

293. Brian Simpson, Human Rights and the End of Empire: Britain and the Genesis of the European Convention (Oxford, New York: Oxford University Press, 2001), 409.

294. Elkins, Imperial Reckoning, 319-321. See also: TNA CO 822/1251: "Dilution Detention Camps," and Ndiku Mutua and Others $v$ The Foreign and Commonwealth Office [2011], appendix B.

295. For more on the International Military Tribunal at Nuremburg and the codification of crimes against humanity, see chapter entitled: “"Unimaginable Atrocities”: Identifying International Crimes," in William Schabas, Unimaginable Atrocities: Justice, Politics, and Rights at the War Crimes Tribunals (Oxford: Oxford University Press, 2012), 25-46. 
have allowed them to benefit from prisoner of war protections. ${ }^{296}$ Although jurisdiction was lacking, humanitarian law offered states a powerful normative framework for upholding standards in the treatment of detainees and prisoners, especially when considering that Nazi concentration camps were liberated by British and American soldiers. These ideals, alongside other obligations of international law that extended to the colony, should have elicited moral abhorrence at what was occurring in the Kenyan camps. However in the $1950 \mathrm{~s}$, Britain and other colonial states took a minimalistic approach to international law obligations vis-à-vis the rights of their colonial subjects, and Klose regards the colonial response to demands for national independence as a combination of measures incorporating rule by emergency laws, an "emphasis on the new military doctrine of antisubversive warfare," and the "refusal to recognize the validity of international humanitarian law," and that these factors underpinned "the unleashing of colonial violence." 297

The United Kingdom government signed the 1930 ILO Forced Labour Convention on June 3, 1931 and it was accepted into Kenya without modification. However, on February 17, 1954 the British Cabinet approved a forced labor policy for the Kenyan detention camps in the following terms " $[\ldots]$ the regulation authorising compulsory employment should contain words to the effect that any person detained in a special detention camp might be usefully employed in work which, in the opinion of the officer in charge, would assist in bringing the Emergency to an end. He [the Colonial Secretary] proposed to instruct the Governor to make the regulation in this form. In these circumstances it would probably be unnecessary to pay market rates of wages for work undertaken by prisoners in the detention camps." 298 Therefore, Regulation 22 of the Emergency (Detained Persons) Ordinance was worded so as to bring it within the meaning of the 2(2)(d) emergency clause. ${ }^{299}$ Notwithstanding these efforts, the ILO Committee of Experts criticized the government's use of forced labor in Kenya

[t]he committee has noted that in response to the observation that was made in 1956 the government declares that the forced or compulsory labour exacted under the laws and regulations in force falls within the exception covered by

296. The Convention (III) Relative to the Treatment of Prisoners of War, August 12, 1949, which applied to conflict not of an international nature, was only extended to the colonies in 1959. Humanitarian law instruments applicable in the colony before that time were the Hague Conventions and the Geneva Convention of 1929.

297. Klose, Human Rights in the Shadow of Colonial Violence, 194, 234.

298. Ibid.

299. See note 197. TNA CO 822/1420: Regulation 22 denotes that the officer in charge should be satisfied that the work "will assist in bringing the Emergency to an end." 
Article 2, paragraph 2(d) (cases of Emergency) and 2(e) (minor communal services). With regard to the regulations relating to a state of Emergency the committee considers that it may assume that the disappearance of the exceptional circumstances which justified the adoption of those regulations will enable the government to apply the letter of the Convention as well as the spirit. $^{300}$

Descriptions of coerced labor depicted in detainees' testimonies are entirely at odds with the idea of purposeful work contributing to the end of conflict. Some of the tasks were manifestly designed to be cruel or punitive, as one detainee reported "[...] at Takwu Detention Camp detainees are working in sea-water, breaking stones along a canal for a continuous period of four hours, clearing mangrove forest trees in water and road making through where canal surface was to be broken with picks... We consider that removing of sanitary buckets for the Officer in charge and warders is purely punitive." ${ }^{301}$ These testimonies suggest there was a violation of the ILO Forced Labour Convention 1930 when the labor exacted did not fall under the treaty's emergency clause, and in instances in which the forced labor policy continued after the emergency officially ended. Could there have been an actionable tort arising from the use of forced labour in the Kenyan camps? Although there may have been a violation of the 1930 Forced Labour Convention, ultimately, allegations of unlawful killing and torture are much more compelling, with the latter forming the backbone of the Mutua and Others claim.

\section{Retrospective Accountability}

The claimants in Mutua and Others submitted an action to the United Kingdom High Court for alleged torts of "assault and battery, and negligence." ${ }^{302}$ Civil actions of the sort rely on a balance of probabilities test. As highlighted in Justice McCombe's summary of the 2011 judgment, ${ }^{303}$ the relevant tort law pertaining to the case is the 1980 Limitations Act, and through Article 33 of that Act, judicial discretion may extend the usual 3 year limitation clause for personal damages. Public interest may be a factor in issuing judicial discretion, and in the instant case, the state's duty was to investigate allegations of torture. At the same time, claimants needed to

300. Ibid.

301. TNA CO 822/402: petition detailing conditions in the camps and presented to Dingle Foot MP upon his inspection of various camps in September 1956.

302. Negligence being a common law duty to intervene or stop systematic abuses once that became known, see Ndiku Mutua and Others $v$ The Foreign and Commonwealth Office, 21/07/2011, Summary of Judgment.

303. Ibid. 
have a reasonable chance of success, to outweigh the huge costs associated with historic actions. Surviving historical documentation may illuminate the "aims and purposes" that the British government had in relation to the colonial emergency, which could establish responsibility for torts. A factor that could influence judicial discretion in waiving the limitation is evidence that the United Kingdom government and the colonial administration had inhibited investigations into camp abuses and restricted the remit of contemporary inquiries. ${ }^{304}$ However, no action in tort may be brought for wrongs that occurred prior to June 23, 1954..$^{305}$ Claims arising from other colonies would need to furnish a United Kingdom court with compelling reasons for a prolonged delay in submitting such a claim. It is notable that in the Kenyan case, the Mau Mau organization was proscribed until 2002-2003, and many of the elderly survivors of abuse resided in remote and rural areas.

Justice McCombe had to decide whether the claimants had a "viable claim in law," and if they had any realistic chances of success with their claim. ${ }^{306}$ As defendants, the FCO argued that acts committed by the colonial government essentially were not acts of the United Kingdom government, and that legal liability for these acts passed to the successor state at independence. This was unchartered legal territory, as counsel for the claimants explained, "Neither the Kenya Independence Act 1963, nor any other UK statute or instrument, addresses the question of the succession of liabilities of the Colonial Administration for assaults against the Claimants." ${ }^{307}$ In such a case, the matter must be decided at common law, but common law has to incorporate international customary law into its decision making. Following consideration of arguments, including the claimants' reliance on postcolonial Algerian jurisprudence against Q9 France, and the defense drawing from the Quark case, Justice McCombe decided that the liabilities of the old colonial regime did not transfer to the United Kingdom at Kenyan independence in 1963. However, under the principle of "joint liability for torts," the United Kingdom government, named as a joint tortfeasor, could still have a case to answer for historic wrongs committed by the army or the Colonial Office, and such matters were fit for trial. ${ }^{308}$ Justice McCombe further examined General

304. Ndiku Mutua and Others v The Foreign and Commonwealth Office [2012], para. 140.

305. Ibid., para. 38, citing Arnold v CEGB [1988] AC 228 and McDonnell $v$ Congregation of Christian Brothers and others [2004] 1 AC 1101.

306. Ndiku Mutua and Others $v$ The Foreign and Commonwealth Office, Summary of Judgment, para. 2.

307. Ndiku Mutua and Others v The Foreign and Commonwealth Office [2011], para. 81(a). 308. Ibid., para. 116. 
Erskine's role in the emergency and he concluded that there was sufficient documentary evidence to suggest Erskine's involvement in the detention system, and that, therefore, the issue was triable. He made similar conclusions in respect of the colonial secretary and the Colonial Office, "[a]11 these matters are, in my judgment, properly triable issues on the evidence before me, including the evidence of the continuing and still incomplete disclosure by the defendant of previously unseen materials. The evidence shows that those new materials were removed from Kenya upon independence precisely because of their potential to embarrass the UK Government." 309

A significant point of dispute between the parties pertained to the role played by the United Kingdom government in the development and control of the detention camps. Both the Kenyan colonial government and the United Kingdom government were very much aware of the "extent of continuing misconduct in the treatment of detainees," and by not making any concerted efforts to stop the abuses, the United Kingdom government neglected their duty of care and could have been found guilty of negligence. However, the role of the United Kingdom government may have gone beyond simple negligence through acts of omission, and if the facts of the case presented by the Mutua claimants could be established, it suggested to Justice McCombe "the distinct possibility of an active direction of policy and an active part in its implementation on the part of Her Majesty's Government" which could only be clarified if the matter went to trial. Given the gravity of the matters being considered, Justice McCombe criticized the United Kingdom government for relying on technical constitutional legal theory so early in the proceedings (in an effort to get the case struck out), in a way the judge described as "dishonourable." 310

The British Prime Minister, Sir Harold Wilson, first accepted the optional clauses to the European Convention (pertaining to individual petitions and the compulsory jurisdiction of the Court) in 1966 for an initial 3 year period. ${ }^{311}$ At the time, it was considered that acceptance would apply only to prospective cases, which was a response to litigation taken by the Burmah Oil Company against the United Kingdom government

Q3 for the destruction of its oil refineries in 1942. Lord Lester's examination of the period leading up to acceptance tellingly reveals little or no discussion of the possibility of colonial legacy issues. ${ }^{312}$ In this event, a temporal

309. Ibid., para. 130.

310. Ibid., para. 154.

311. Ed Bates, The Evolution of the European Convention on Human Rights: From its Inception to the Creation of a Permanent Court of Human Rights (Oxford: Oxford University Press, 2010), 185.

312. Lord Lester of Herne Hill, "UK Acceptance of the Strasbourg Jurisdiction: What Q26 Really Went on in Whitehall in 1965," Public Law (1998): 237. 
limitation was incorporated, "into the U.K.'s declaration of acceptance a limitation making it clear that acceptance applied only to matters arising after its effective date, thereby excluding a once-and-for-all action of the kind taken in connection with the Burmah Oil claims, occurring before that date." 313 This declaration effectively annulled approximately eighty applications that had been received by the Commission in anticipation of Britain's acceptance of the optional clauses, but equally, the declaration "did not extend to petitions relating to matters arising in any dependent territory, or to anything done or occurring in the United Kingdom in respect of any such territory or of any matters arising there." 314 The 2014 "Practical Guide on Admissibility Criteria," produced by the European Court of Human Rights, notes that when countries have drafted declarations with temporal limitations, "the Commission and the Court have accepted temporal limitations of their jurisdiction with respect to facts falling within the period between the entry into force of the Convention and the relevant declaration." ${ }^{315}$ However, the evolving jurisprudence of the Court has provided for exceptions to the test criteria on admissibility per ratione temporis, 316 and such consideration can occur when the right to life (Article 2) is violated or breaches of the prohibition on torture (Article 3) are alleged. It is significant that the Court in Silih v Slovenia elaborated the concept of procedural detachability applying to the right to life. In essence, this means that the state's investigation into a death may be examined by the Court even if the substance of the claim occurred prior to the Court assuming jurisdiction in that member state's territory. The criteria outlined in Silih v Slovenia are not unlimited, and must be in accordance with the principle of legal certainty:

162. First, it is clear that, where the death occurred before the critical date [entry into force of the Convention], only procedural acts and/or omissions occurring after that date can fall within the Court's temporal jurisdiction.

163. Second, there must exist a genuine connection between the death and the entry into force of the Convention in respect of the respondent State for the procedural obligations imposed by Article 2 to come into effect.

Thus a significant proportion of the procedural steps required by this provision-which include not only an effective investigation into the death of the person concerned but also the institution of appropriate proceedings for the purpose of determining the cause of the death and holding those responsible

313. Ibid., 252.

314. Ibid., 253.

315. European Court of Human Rights, Practical Guide on Admissibility Criteria, 47, para. 199.

316. This test criteria is set out in Blečić v. Croatia, (Application no. 59532/00), March 8, 2006, para. 67. 
to account. . - - will have been or ought to have been carried out after the critical date.

However, the Court would not exclude that in certain circumstances the connection could also be based on the need to ensure that the guarantees and the underlying values of the Convention are protected in a real and effective manner. 317

Of these, perhaps the latter Convention values test is most significant to the current discussion, but it is also notable that the detachability principle has been invoked by the Court to examine investigations into torture and illtreatment, where, in the main, proceedings occurred after the entry into force of the Convention, whereas the actual violation preceded that critical date. ${ }^{318}$ Therefore, although the United Kingdom only accepted individual petition mechanism in 1966, applicants to Europe could argue that they were prevented from accessing a remedy for these most serious violations, not merely because of the temporal limitation on the state's declaration, but because of historic, structural, and evidentiary legal obstacles, and that fresh evidence coming into the public domain via the Hanslope Disclosure cast a new light on the circumstances of historic violations. ${ }^{319}$ Claimants in the Mutua and Others case argued that the coming into being of the Human Rights Act, and the unearthing of voluminous documentation in 2005 and 2011, triggered a duty upon the state to investigate allegations of torture, and that the procedural obligation attached to this article was "revived." 320

Another possibility would be to argue the Convention values test, as a short period in between the violation and the entry into force of the Court's jurisdiction was established in the Silih judgment. ${ }^{321}$ The Court may depart from this rule and permit a "further extension of the Court's jurisdiction into the past... if the triggering event has a larger dimension which amounts to a negation of the very foundations of the Convention (such as in cases of serious crimes under international law), but only to events which occurred after the adoption of the Convention, on 4 November 1950."322 Torture was "institutionalised and systematic, but

317. Silih v. Slovenia, (Application no. 71463/01), April 9, 2009, paras. 161-63.

318. Yatsenko v Ukraine, (Application no. 75345/01), February 16, 2012, para. 40; Lyubov Efimenko v. Ukraine, (Application no. 75726/01), November 25, 2010, para. 63.

319. Janowiec and Others v Russia, (Applications nos. 55508/07 and 29520/09), April 16, 2012, para. 139.

320. Ndiku Mutua and Others v The Foreign and Commonwealth Office [2012], paras. $142,147$.

321. The Practical Guide on Admissibility Criteria states "not exceeding ten years," para 212.

322. Ibid., 214. 
also casual and haphazard" during the emergency in Kenya. ${ }^{323}$ Practices associated with "screening" or the interrogation of Mau Mau suspects included whipping, beatings, use of electric shock, administering cigarette burns, Chinese water treatment, sexual violence, and sterilization. ${ }^{324}$ The claimants in Mutua and Others experienced "physical mistreatment of the most serious kind, including torture, rape, castration and severe beatings" while in detention. ${ }^{325}$ In this light, the scale of the abuses that occurred within a network of extrajudicial camps established not 10 years after the liberation of Nazi concentration camps might be considered a negation of the very values enshrined in the European Convention that encapsulated a postwar abhorrence of violence and human degradation.

\section{Conclusion}

This article examines the legal regime that facilitated the detention without trial of somewhere between 80,000 and 150,000 people during the Kenyan emergency. Abuses that occurred in the detention camp network were highlighted through a thematic study. In general terms, detention laws and ordinances appear far removed from the environment that facilitated torture, mistreatment, starvation, and forced labor. However, as Samera Esmeir points out, a condition of rightlessness does not necessarily mean "expulsion from the law." 326 The emergency regulatory framework in Kenya facilitated the "lawful" confinement of Kikuyu subjects, and the bare violence of the system was translated into a language of euphemism, through the invention of nomenclature such as "dilution," "screening," and "the Mwea procedure." These techniques occurred in camps that represented the "spatialization of the colonial state of emergency," 327 and this architecture dehumanized detainee suspects, and it is, therefore, essential for the essential humanity of those affected to be finally recognized. It is doubtful whether William Hague's "apology" achieves this "[o]n behalf of Her Majesty's Government, that we understand the pain and grievance felt by those who were involved in the events of the Emergency in Kenya. The British Government recognises that Kenyans were subject to torture and other forms of ill treatment at the hands of the colonial administration. The British government sincerely regrets that these abuses took place, and

323. Elkins, Imperial Reckoning, 293.

324. Anderson, Histories of the Hanged, 65-68; 208-209.

325. Ndiku Mutua and Others v The Foreign and Commonwealth Office [2011], para. 1.

326. Esmeir, Juridical Humanity, 93.

327. Klose, Human Rights in the Shadow of Colonial Violence, 236. 
that they marred Kenya's progress towards independence." 328 It is submitted that this "recognition" falls short of fully accepting responsibility for colonial era abuses in Kenya, especially as a foregoing paragraph alludes to Mau Mau "guilt" for 2,000 emergency-related deaths, whereas no comparable figure is given for state-sponsored killings, "[d]uring the Emergency Period widespread violence was committed by both sides, and most of the victims were Kenyan. Many thousands of Mau Mau members were killed, while the Mau Mau themselves were responsible for the deaths of over 2,000 people including 200 casualties among the British regiments and police." 329 Violence was used to elicit intelligence and enforce compliance with detention regimes in other colonies. ${ }^{330}$ It is submitted, however, that the pernicious fusing of a "civilizing mission" with counterinsurgency strategy underpinned by a racist ideology resulted in deadly violence against detainees in the Kenyan camps. This unholy convergence demands a reassessment of the historical narrative regarding the "defeat" of the Mau Mau insurgency in Kenya.

Moreover, the article clearly argues that a culture of whitewash and denial framed the manner in which colonial officials in Kenya and London responded to allegations of detention-based violence and abuses that surfaced, which was certainly not unique to the colony of Kenya. Government ministers, such as the colonial secretary, endorsed a quasilegal regulatory framework that resulted in violence; however, to keep the violence hidden, a discourse constructed around the "rehabilitative" nature of detention camps was publicly narrated, further constricting the space for detainees to access justice. The Hanslope files, read alongside other declassified documents, reveal a general trend toward concealing detentionbased violence at local, colonial, and metropolitan levels, depending upon the exigencies of the situation. The overarching framework of concealment, was, at times, punctuated by acknowledgement of these acts when irrefutable evidence entered the public domain (as was the case with the Hola Massacre). The article highlights how unresolved or unacknowledged detention-based violence, torture, or mistreatment, even for events that occurred many decades ago, may have contemporary salience.

328. Hague, "Statement to Parliament on settlement of Mau Mau claims."

329. Ibid.

330. French, The British Way in Counter-Insurgency. See also Klose, Human Rights in the Shadow of Colonial Violence. 